RADOVI

Zavoda za znanstveni rad HAZU Varaždin

JERE DRPIĆ

Gradski muzej Varaždin

drpic.jere@gmail.com
UDK 666.32:688.9:069(497.523Varaždin)

Prethodno priopćenje

Preliminary Communication

Primljeno: 14. 09. 2018.

Prihvaćeno: 14. 11. 2018.

DOI: https://dx.doi.org/10.21857/moxpjhg28m

\title{
GLINENE LULE IZ FUNDUSA ARHEOLOŠKOG ODJELA GRADSKOG MUZEJA VARAŽDIN
}

\begin{abstract}
U ovom radu obrađuju se glinene lule za pušenje, koje se čuvaju u zbirkama Arheološkog odjela Gradskog muzeja Varaždin. Većina nalaza prikupljena je arheološkim istraživanjima uže gradske jezgre Varaždina, ali ima ih i nekoliko sa šireg područja Varaždinske županije. Lule obuhvaćene ovim radom pripadaju dvjema osnovnim skupinama; zapadnoj i istočnoj i dvama tipovima istočne skupine; turskom i austrougarskom. Datacija ovih predmeta je od sredine 17. st. do kraja 19. stoljeća.
\end{abstract}

\section{UVOD}

Sve glinene lule koje se čuvaju u fundusu Arheološkog odjela Gradskog muzeja Varaždin, izuzev jedne, su pronađene tijekom arheoloških istraživanja. Većina ih je u muzej pristigla istraživanjem najstarijeg dijela grada Varaždina, utvrde Stari grad, ali isto tako i prilikom arheoloških nadzora u staroj jezgri grada. Kako područje djelovanja GMV-a obuhvaća ne samo grad Varaždin nego i Varaždinsku županiju, tako su u muzej stigle i lule iz Lepoglave i špilje Vindije. Ukupan broj ovih predmeta $u$ dvijema muzejskim zbirkama je trideset. Kako dolaze iz arheološkog konteksta, većinom su fragmentalno sačuvane. Iako fragmentirane, katalogizacijom i tipološkom kvalifikacijom te kroz analogije s prostora Hrvatske i zemalja bližeg okruženja, ti fragmenti nam omogućavaju dobivanje šire slike o proizvodnji, distribuciji i upotrebi glinenih lula na prije spomenutom prostoru na kojemu su nađene. Na tome će se ovaj rad bazirati. 
Običaj pušenja duhana u glinenim lulama u Europu je stigao posredstvom europskih mornara, koji su ga preuzeli od američkih indijanaca. Sve veća popularnost pušenja uzrok je da se u 16. st. u Engleskoj izrađuju prve europske glinene lule, a do početka 17. st. to je slučaj i u ostalim europskim gradovima te Osmanskom carstvu. Posljedično se zbog utjecaja raznih kultura razvijaju i raznovrsni tipovi. ${ }^{1}$ Običaj pušenja u glinenim lulama nije zaobišao niti prostor Varaždina i Varaždinske županije, naprotiv, bio je jako popularan sve do samog

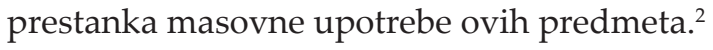

\section{OSNOVNA TIPOLOGIJA EUROPSKIH GLINENIH LULA}

Prema zemljopisnom podrijetlu europske lule možemo podijeliti na dvije velike skupine. To su zapadna i istočna ili mediteranska skupina. Zapadnoj skupini se pripisuje proizvodnja jednodijelnih lula, kod kojih je $\mathrm{u}$ jednom komadu u kalupu izrađen kamiš, ${ }^{3}$ tuljac i čašica, s jednom veznom rupom. Prema proizvodnim centrima dalje ovu skupina možemo podijeliti na njemačku, englesku, nizozemsku, skandinavsku, španjolsku i francusku proizvodnju. Kod dvodijelnih lula posebno je izrađivana čašica s tuljcem i kamiš koji je najčešće bio od drva ili trstike. Ovaj oblik je karakterističan za istočnu skupinu. Postoji više tipova koji se javljaju unutar ove skupine. Za ovaj rad su najbitniji austrougarski s podtipom kavanskih lula i turski tip. Svi ovi tipovi su se proizvodili u raznim europskim radionicama, koje je prema određenim karakteristikama bilo moguće prepoznati. ${ }^{4}$

Curt MARONDE, Rund um Tabak. Frankfurt am Main, 1976, 17; Rebecca C. W. ROBINSON, Tobacco pipes of Corinth and of Athenian Agora. Hesperia 54-2/1985., 149-153; Luka BEKIĆ, Uvod u problematiku glinenih lula na području Hrvatske, Vijesnik Arheološkog muzeja u Zagrebu, 3.s., XXXII-XXXII, 1999./2000., 249, 250-254.

2 Uporaba keramičkih lula održala se u Europi sve do kraja 19. st., pojavom cigareta u 20. st. u potpunost ovi predmeti gube na značaju; R. C. W. ROBINSON, n. dj., 152; Iain GATELY, Tobacco: A Cultural History of how an Exotic Plant Seduced Civilization, Grove Press, London, 2001., 206-212.

3 Kamiš je naziv za cijev kroz koju se uvlači dim iz lule, tur. Kamiş je riječ koja označava trstiku. Divna GAČIĆ, The pipes from Museum Collections of Serbia, Muzej grada Novog Sada, Novi Sad, 2011., 28.

$4 \quad$ Prvi je tipologiju za lule nađene u Hrvatskoj po proizvodnim centrima iznio Luka Bekić; L. BEKIĆ, Uvod u problematiku glinenih lula na području Hrvatske, 250-254; Karla GUSAR, Arheološki nalazi keramičkih lula za duhan iz zbirke Narodnog muzeja u Zadru, Prilozi instituta za arheologiju Zagreb, 25/2008., 135-146. Zbog ograničenosti teksta u nastavku će bit riječ samo o onim tipovima kojima pripadaju lule iz zbirki Arheološkog odjela GMV-a. 


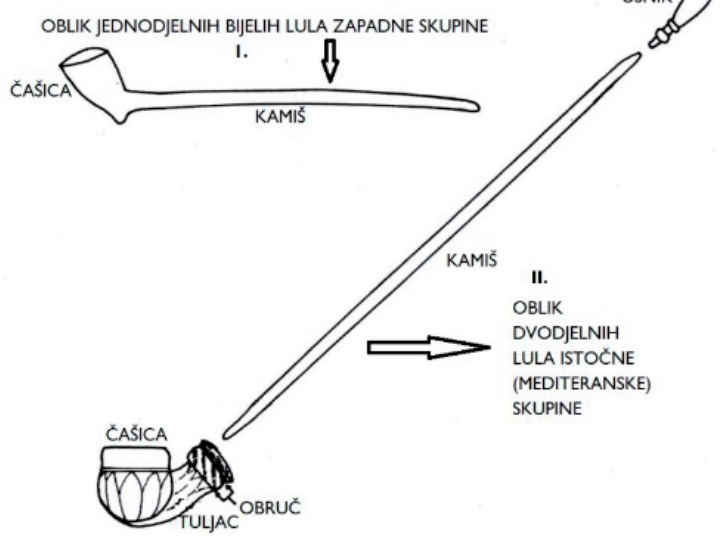

Slika 1. Prikaz osnovnih skupina i oblika keramičkih lula. Preuzeto iz; R. C. W. ROBINSON, n.dj., 154, sl. 1.

\section{GLINENE LULE IZ ZBIRKI ARHEOLOŠKOG ODJELA GMV-A}

Među korpusom od trideset lula koliko ih se čuva na ovom odjelu, samo jedna pripada zapadnoj skupini, kat. 1 (T. I-1). Možemo je prepoznati prema bijeloj boji zbog kaolinske gline, od koje su ovakve lule uglavnom izrađivane. ${ }^{5}$ Nađena je u mokrom jarku varaždinskog Starog grada, u tamnom, tvrdom i nabitom sloju (mulj), gotovo crne boje, koji se datira u 16.-17. stoljeće. Prvi je to primjerak ovakvog tipa s područja kontinentalne Hrvatske. ${ }^{6}$ Nažalost, sačuvan je samo manji dio čašice, bez pečata s jednom veznom rupom. ${ }^{7}$ Njeno podrijetlo je zbog toga teško točno utvditi, međutim usporedimo li je s lulama zapadne skupine pronađenim na istočnoj obali Jadrana tj. u Istri i Zadru, tada možemo govoriti o mogućem engleskom ili nizozemskom podrijetlu. ${ }^{8}$ Kada sagledamo kontekst u kojemu

5 Amoret SCOTT, Christopher SCOTT, Discovering smoking antiques. Tring: Shire, 1970., 15; Ralf KLUTTING-ALTMANN, 1998./99., Mehr als blauer Duns - Tönerne Tabakspfeifen aus Laipziger Stadtkerngraburgen, Archaologie aktuell 6, Fraistaat Sachsen, 1998./99, 146-153.; L. BEKIĆ, Uvod u problematiku glinenih lula na području Hrvatske, 250-252.

6 Prema dosad dostupnoj literaturi o lulama u Hrvatskoj.

7 Po fragmentu mrljasti ostaci korodiranog metala.

$8 \quad$ K. GUSAR, n. dj., 139, 140, kat. 1, T.1, 1; Luka BEKIĆ, A Brief Introduction to Clay Pipe Finds in Croatia With Special Attention to Local Pipes Found at Fort Čanjevo in The Kalnik Hills. U: Journal of the Académie Internationale de la Pipe, Vol. 3, 2010, 1; Luka BEKIĆ, Novovjekovne lule i boce iz podmorja Istre / Post medieval Pipes and Bottles from the Istrian Seabed, Istra u novom vijeku / Istria in the modern period, Monografije i katalozi Arheološkog muzeja Istre u Puli 30, Pula, 2017., 275- 
je ova lula pronađena, podrijetlo bi trebalo možda tražiti u nekoj od njemačkih radionica. Naime mnogi vojnici njemačkog podrijetla početkom novog vijeka su kao branitelji utvrde, boravili u varaždinskom Starom gradu, u čijem mokrom jarku je pronađen ovaj fragment. Može se pretpostaviti da su ti vojnici sa sobom donijeli i običaj pušenja u lulama iz svojih krajeva. Prisustvo njemačkih vojnika je vidljivo i iz sudskog spora s kraja 16. st. kad je suđeno jednom od njih, a navodi se da je bio plaćenik u utvrdi Varaždin. Također, o njihovom prisustvu svjedoči podatak da se Vlaška komisija u 17. st. protivi odlasku njemačkih vojnika iz Varaždina i varaždinske tvrđe. ${ }^{9}$ Zbog relativno male čašice tipološki se može okvirno datirati u 17. st. ${ }^{10}$ Ostale lule se pripisuju istočnoj skupini njih dvadeset i devet (kat. br. 2-30). Iz istočne skupine u zasebnu grupu bilo je moguće izdvojiti one turskog tipa (kat. br. 2-6). Ukupno ih je pet primjeraka. Tri primjerka su nađena unutar sjevernog mokrog jarka varaždinskog Starog grada (kat. br. 2, 3, 6), a dvije u špilji Vindiji (kat. br. 4, 5).

Lule iz jarka varaždinskog Starog grada su sve nađene u sustavnim arheološkim istraživanjima. Primjerci kat. 3, 4 (T. I-3, 4) su vjerojatno rad iste nepoznate radionice turskog tipa lula. Obje su fragmentirane na dijelu čašice, sive su boje, rađene $u$ kalupu, s jednom veznom rupom. Ukrasi su izvedeni utiskivanjem (pečaćenjem), kotačićem (T. V-1, 3). ${ }^{11}$ Izravnu analogiju za ove primjerke imamo u lulama s utvrde Čanjevo i Sv. Helena. ${ }^{12}$ Luli kat. 5 (T. II-5) sačuvan je samo tuljac sa obručem, s jednom veznom rupom. Pečena je crno s dekoracijom istom kao i prethodno opisani predmeti samo drukčijom izvedbom (T. V-2). Ponovno na utvrdi Čanjevo imamo analogiju. ${ }^{13}$ Lula kat. 6 (T. II-6) malo je drukčijih karakte-

276; I u susjednoj Sloveniji, u rijeci Ljubljanici, pronađeno je više cijelih i fragmentiranih lula, od kojih se samo jedan primjerak pripisuje zapadnoj skupini (engleski tip), dok su ostale iz istočne skupine, vidi u; Blaženka FIRST, Mateja KOS, Darija MAVRIČ, D., Tomaž NEBERGOJ, Nika VERŠNIK N., Matija ŽARGI., 2009., Modern period, The Ljubljanica - a river and its past, Ljubljana, 2009, 420-421.

9 Mira ILIJANIĆ, Varaždin u 16. st., Radovi Zavoda za znanstveni rad Jugoslavenske akademije znanosti i umjetnosti, 2, Varaždin, 1988., 452; Rudolf HORVAT, 1993., Povijest grada Varaždina, Hrvatska akademija znanosti i umjetnosti - Zavod za znanstveni rad, Varaždin, 1993., 173.

10 Lioyd EDWARDS, The Archaeology of the Clay Tobacco Pipe, XI. Seventeenth and Eighteenth Century Tyneside Tobacco Pipe Makers and Tobacconists, BAR, British series 192, 1988., 8-13.

11 Dekoracija od 6 trokutića razmještenih u obliku cvijeta sa svake strane čašice. Cvijetove omeđuju kružnice izvedene kotačićem. Prstenovi se međusobno dodiruju na dnu grebena.

12 Luka BEKIĆ, A Brief Introduction to Clay Pipe Finds in Croatia With Special Attention to Local Pipes Found at Fort Čanjevo in The Kalnik Hills, Journal of the Académie Internationale de la Pipe, Vol. 3., 2010., 3, (kat. 1) 6, (kat.18).

13 L. BEKIĆ, A Brief Introduction to Clay Pipe Finds in Croatia With Special Attention to Local Pipes Found at Fort Čanjevo in The Kalnik Hills, 3, (kat. 4.) Lula se datira prema srebrnom novcu 
ristika od prethodno opisanih. Tuljac je kratak te naglašen većim obručem, koji je dodatno ukrašen kosim urezivanjem, u obliku turbana. Čašica je malih dimenzija i ukrašena je dubljim okomitim kanelurama. Spoj čašice i tuljca ukrašen je kotačićem i urezanim linijama i povezan jednom rupom. I za ovaj primjerak analogiju pronalazimo na utvrdi Čanjevo. ${ }^{14}$ Zadnja lula u ovoj grupi kat. 2 (T. I-2) je i najbolje sačuvana ovog tipa u zbirci, nedostaje joj samo dio grebena. Malih je dimenzija $\mathrm{s}$ jednom veznom rupom i izraženim grebenom. Čašica je u donjem dijelu loptasta, u gornjem dijelu cilindrična. Tuljac je kratak s većim diskoidnim obručem, ukrašen je s linijom kotačića, a dvije ovakve paralelne linije su i na otvoru čašice. Prijelaz iz cilindričnog dijela čašice u loptasti, naznačen je štapičastim motivima u nizu, a loptasti je ukrašen paralelnim dubokim urezanim linijama. Ukras grebena je izveden kotačićem. Greben je od tuljca vizualno odvojen sa cik-cak i štapičastim motivom, a u nastavku tuljca se nalaze dva dublje urezana žlijeba, sa po dva prstena ukrašena kotačića. Analogiju za ovu lulu pronalazimo među lulama otkrivenim na slavonskom lokalitetu Zoljani-Čemešac I. ${ }^{15}$ Sve prethodno obrađene lule turskog tipa imaju posebice puno paralela sa onima nađenim $u$ brodolomu kod Bisaga (Kornati), te nalazima sa utvrde Čanjevo koja se nalazi na rubu Varaždinske županije. ${ }^{16}$

Slični primjerci su pronađeni i u rijeci Dravi nedaleko mađarskih gradova Barcs, Babocsa, Sigetvar, ali i utvrdi Ružica nedaleko Orahovice. ${ }^{17}$ Točne radionice ovih lula je teško odrediti zbog sličnog dekorativnog i oblikovnog koncepta sa originalnim turskim lulama, međutim razlika je očita. ${ }^{18}$ Sve ovdje obrađene pokazuju izravnu analogiju s grupom, kako ih L. Bekić naziva “Borderland-type

Leopolda I. u 1687. god.; Luka BEKIĆ, Glinene lule s utvrde Čanjevo, Utvrda Čanjevo. Istraživanja 2003-2007. Visoko: Hrvatski restauratorski zavod; Općina Visoko, 2008., 191-195.

14 L. BEKIĆ, A Brief Introduction to Clay Pipe Finds in Croatia With Special Attention to Local Pipes Found at Fort Čanjevo in The Kalnik Hills, 4, (kat. 12). Lula se datira prema srebrnom novcu Leopolda I. u 1687. god.

15 Autori ovu lulu (kat. 39) okvirno datiraju u 18.-19, st.- te je pripisuju turskom tipu. Lula je nađena u humusnom sloju; Marija ŠIŠA-VIVEK, Krešimir FILIPEC, Keremičke lule s lokaliteta Zoljani Čemešac I, Opuscula archaeologica 37/38, 2013./2014., 311, 328.

16 Zdenko BRUSIĆ, Dio tereta s lađe iz 17. stoljeća potonule kod otoka Bisaga u Kornatskom arhipelagu Prilozi povijesti umjetnosti u Dalmaciji 26/1986/87, 473 - 490; L. BEKIĆ, Glinene lule s utvrde Čanjevo, 191-195; Utvrda Čanjevo nalazi se južno od grada Varaždina, udaljena 23 km zračne linije.

17 Gyöngyi KOVACS, Rozsas MARTON, KORA ÚJKORI CSERÉPPIPÁK A DRÁVA VIDÉKÉRŐL, Egység, regionalitás, kereskedelem, Archaeologiai Értesítő 139, Budapest, 2014., 239-259; Mladen RADIĆ, Zvonko BOJČIĆ., Srednjovjekovni grad Ružica. Katalog izložbe, Osijek: Muzej Salvonije, 2004., 218, 219.

18 R. C. W. ROBINSON, n. dj., 149-153. 
pipes", tj. "krajiškim" lulama, podtipom turskih lula čije podrijetlo je još uvijek nejasno, a javljaju se u sjevernoj Hrvatskoj uz nekadašnju granicu sa Osmanskim carstvom, posebice u militariziranim područjima kao što su utvrde. ${ }^{19}$ Upravo to je slučaj i s ovim lulama, uz specifičnost onih iz špilje Vindije.

Sljedeću grupu ovih predmeta čini tzv. austrougarski tip ${ }^{20}$ koji se vezuje uz radionice na prostoru nekadašnje Austrougarske, tj. Habsburške monarhije, 18. i 19. st. Ovaj tip obuhvaća proizvodnju visoko kvalitetnih dvodjelnih lula iz radionica u Slovačkoj, Austriji i Mađarskoj. Posebno važan centar proizvodnje bio je u mjestu Banska Štiavnica ${ }^{21}$ (Slovačka). Upravo lule iz ovog gradića bile su tijekom najveće popularnosti u 18. i 19. st. svojevrsni „brend“ koji je garantirao kvalitetu, pa su ga mnoge mađarske i austrijske radionice imitirale. To je rezultiralo pojavom velikog broja radionica ovog obilka lule $u$ svim navedenim zemljama. ${ }^{22}$ Primjerci kat. 7, 8, 9 (T.III-7, 8, 9) nađeni su u Vodnikovoj ul. nedaleko od Varaždinske utvrde $u$ arheološkim istraživanjima. Prema pečatu na tuljcu ali i radi karakteristične izrade, njih možemo pripisati upravo ranije u tekstu spomenutoj proizvodnji u Banskoj Štiavnici tj. radionici Michala Höniga. ${ }^{23}$ Izrađene su u kalupu, crno pečene te uglačane površine. Čašice su izvana osmerokutne a iznutra kružne, dok su im grebeni u obliku školjke. Međusobno se razlikuju prema ukrasu na obruču, pa su tako primjerci kat. 8, 9 ukrašeni kosim paralelnim linijama, a kat. 7 je ukrašen mrežastim motivom. Na tuljcu svi primjerci imaju pravokutni pečat, na kojima se bolje ili lošije razaznaje natpis M.HONIG /SCHEMNITZ (T. VI-16, 18, 22). Na drugoj strani tuljca, kod lula kat. 7, 8 se nalazi kružni pečati s reljefnim motivom poprsja (T. VI-16, 19). Sljedećem primjerku kat. 10 (T.-II-10) nije poznato nalazište, a istih je karakteristika kao i ovi prethodno opisani, s razlikom da je obruč bez ukrasa i zaobljen. Na pečatu se samo razaznaju slova

19 L. BEKIĆ, Glinene lule s utvrde Čanjevo, 194; L. BEKIĆ, A Brief Introduction to Clay Pipe Finds in Croatia With Special Attention to Local Pipes Found at Fort Čanjevo in The Kalnik Hills, 6,7; L. BEKIĆ, Duhanske lule iz nekadašnje vojarne sv. Nikola u Zadru, Sveti Nikola u Zadru, Arheološko iskopavanje u samostanskom sklopu sv. Nikola u Zadru, 2014.-2016., Zadar, 2017., 137-149. L. BEKIĆ, Duhanske lule iz nekadašnje vojarne sv. Nikola u Zadru, 139-141.

21 Njemački zvan Schemnitz.

22 Mario BIELICH, Marian ČURNY, Pipe finds from Nitra and Nitra pipe production, Studies in Post-medieval Archaeology 3, Prague, 2009., 345-354.

23 Zoltan NAGY, Transdanubian Pipe Manufacturers Associated with Selmecbánya, The History of the Hungarian Pipemaker's Craft: Hungarian History through the Pipemaker's Art, Budapest: Hungarian National Museum, 2000, 46-50; Martin VYŠOHLID, Keramické dýmky v archeologických nálezech a jejich vypovídací možnosti : Clay tobacco pipes in the archaeological finds and their ability to testify, Archeologie ve Strednich Čechach 13, 2009., 986-990; Divna GAČIĆ, n.dj., 34; L. BEKIĆ, Uvod u problematiku glinenih lula na području, 255, 256. M. BIELICH, M. ČURNY, n.dj., 345, 346. 
MHO(...) (T. VII-24). Lula kat. 11 (T.II-11) također dolazi iz radionice Michala Höniga. Najbolji je to sačuvani primjerak od svih koje ovdje obrađujemo. Nađena je u samostanskom kompleksu u Lepoglavi zajedno s metalnim poklopcem za čašicu, te djelomično sačuvanim metalnim dijelom oko ruba čašice, koji je ukrašen perforacijama. Poklopac je izveden u obliku cvijeta s kukicom S oblika, za prihvat na obod čašice. Jedino oštećenje je rupa na dijelu čašice. Za razliku od ostalih, lula kat. 11 nema školjkasti greben. Natpis na pečatu glasi M:HÖNIG. WWE SCHEMNITZ (T. VI-18). ${ }^{24}$ Što se tiče analogija za ovu grupu s M HÖNIG pečatom, najbliža je lula nađena na Starom gradu u Ivancu, ${ }^{25}$ dok najviše izravnih analogija imamo u Dubrovniku, gdje je na lokalitetu Kula Gornji ugao ${ }^{26}$ pronađeno pet primjeraka ovakvih karakteristika. Jedna ovakva lula nađena je i u $\mathrm{BiH}$, točnije na tvrđavi u Doboju, ${ }^{27}$ a više njih u Srbiji. ${ }^{28}$ Analogiju nalazimo i u Nitri ${ }^{29}$ te Pragu. ${ }^{30}$ Datacija svih analognih primjeraka je oko 1830. god., pa tako datiramo i naše primjerke. Zanimljiva je lula kat. 12 (T.II-12) koja je istih karakteristika kao i prethodno opisana grupa, međutim ne pripada radionici M. HÖNIG. Naime, na tuljcu ima pečat sa natpisom SELMECZ (T. VI-22), te je zbog toga treba determinirati kao produkt mađarskih radionica, koje su kopirale lule iz Schemnitza i stavljali na njih mađarski naziv; Selmecz. ${ }^{31}$ Možemo je usporediti s lulom iz Srbije koja je iste izrade sa natpisom Takacz/Selmecz, a datira se u 19. st. ${ }^{32}$ Jako dobre

24 M. BIELICH, M. ČURNY, n.dj., 346; Autori navode da se na nalazima ovih lula iz Slovačke redovito nalaze pečati sa dodatkom slova W I Wc iza imena HÖNIG, ali nigdje ne spominju primjerke sa WWE oznakom, niti značenje te oznake. Ovakav natpis spominje i D. Gačić kad navodi najčešće pečate ove radionice; D. GAČIĆ, $n$. dj., 33. Za ovu lulu kat. 11 sa sačuvanim poklopcem, analogija; Walter MORGENROTH, Das Geheimnis Der Echten Schemnitzer Tabakspfeifen, KnasterKOPF 14, Höhr-Grenzhausen 2001., 55, sl. 1.

25 L. BEKIĆ, Uvod u problematiku glinenih lula na području Hrvatske, 265, Tab. 4 - 7, 8; Juraj BELAJ, Ivanec kroz slojeve prošlosti; deset godina arheoloških istraživanja u Ivancu, 2008., 15, sl. 23 c.

26 Branka MILOŠEVIĆ, Nikolina TOPIĆ, Keramičke lule s lokaliteta Kula Gornji ugao u Dubrovniku., Starohrvatska prosvjeta III. serija - svezak 38, 2011., 302-304, Sl. 5, 5a, sl. 6, 6a, sl. 7, 7a, sl. 8, 8a, sl. 9, sl. 10.

27 Aleksandar JAŠAREVIĆ, Keramičke lule za duvan iz arheološke zbirke Muzeja u Doboju, Radovi, knjiga 5, Sarajevo, 2018., 233, kat. 40, tab. I/20.

28 D. GAČIĆ, n. dj., 125, 126., kat. 174, 183.

29 M. BIELICH, M. ČURNY, n.dj., 345, fig. 7, d, e, f.

30 M. VYŠOHLID, Keramické dýmky v archeologických nálezech a jejich vypovídací možnosti: Clay tobacco pipes in the archaeological finds and their ability to testify, 989, Obr. 24.-a, b, c.

31 Z. NAGY, n.dj., 46-50; M. VYŠOHLID, Keramické dýmky v archeologických nálezech a jejich vypovídací možnosti, Clay tobacco pipes in the archaeological finds and their ability to testify, 988; D. GAČIĆ, n.dj., 34; M. BIELICH, M. ČURNY, n.dj. 348. 349.

32 D. GAČIĆ, n.dj., 126, kat. 175. 
imitacije lula iz Banske Štiavnice su i primjerci kat. 13 i 14 (T.III-13, 14). Proizvodi su to prema pravokutnim pečatima na tuljcima dviju radionica; Bodnar, kat. 13 i Leopolda Grossa, kat. 14. Istog su načina izrade u kalupu, a korištena je i ista narančasto-smeđa boja gline, kod oba primjerka. Čašica je visoka i osmerokutna, a tuljac kratak i okrugli. Imaju jednu veznu rupu i greben u obilku školjke. Obruč koji je sačuvan na Bodnar luli je ukrašen crticama. Također ona je i općenito bolje sačuvana, te se jako dobro vidi pečat na tuljcu, sa natpisom u dva reda; BODNAR SCHEMNITZ (T. VI-12). Drugoj luli nedostaje veći dio tuljca i čašice, ali se dobro vidi pečat LEOP. GROSS SCHEMNITZ (T. VI-13). S druge strane tuljca na ovoj luli nalazi se mali pečat u obliku medaljona sa točkastim motivom, vjerojatno prikaz poprsja. (T. VI-14).

Lula sa pečatom Leopold Gross, njih trinaest je pronađeno u Dubrovniku. ${ }^{33}$ Istog su oblika, izrađene od svijetlije gline sa ovalnim pečatom, za razliku od lule kat. 14. Više sličnosti u kvaliteti, boji gline i izgledu pečata, ovaj primjerak ima s onima drugih radionica iz Banske Štavnice. ${ }^{34}$ Analogiju za lulu kat. 13, s pečatom Bodnar imamo iz Pule. ${ }^{35}$ Zasada lulama s ovakvim pečatima nije otkriveno točno podrijetlo, pa se smiještaju općenito u grupu mađarskih radionica iz gradova Körmend, Bonyhád, Vasvár i Pápa. ${ }^{36}$ Bodnar lulu zbog veličine, te zbog manjka analogija datiramo okvirno u drugu pol. 19. st., dok bi onu s Leop. Gross natpisom trebalo datirati u sredinu 19. st., prema sličnim primjercima iz Slovačke i Hrvatske. ${ }^{37} \mathrm{~S}$ ovim dvjema ranije obrađenim lulama tipološki možemo povezati još dvije lule, kat. 15 i 16 (T.III-15, 16). One su istog oblika kao i prethodno opisane, ali su manjih dimenzija i nemaju nikakav radionički pečat. Obje pokazuju iste karakteristike. Izrađene su od svijetlocrvene gline, u kalupu. Specifičnost im je engobirana i zeleno, smeđe glazirana površina. Imaju jednu veznu rupu, obruč na samom kraju tuljca, te nisu ukrašene. Na luli kat. 15, je sačuvan greben

33 B. MILOŠEVIĆ, N. TOPIĆ, Keramičke lule s lokaliteta Kula Gornji ugao u Dubrovniku, 307-310, sl. 18-28. Navode da je otiskivanje obaju pečata jednog do drugog uobičajeno na lulama koje potječu iz radionice Leopolda Grossa, dok se na lulama iz Schemnitza nalazi po jedan pečat sa svake strane tuljca; Branka MILOŠEVIĆ, Nikolina TOPIĆ, Nalazi keramičkih lula s lokaliteta Sv. Marija od Kaštela i Posat od Ploča u Dubrovniku, Starohrvatska prosvjeta III. serija - svezak 39/2012., 262, tab. 2-2, 2a. ZEJNILHODŽIĆ, Lule iz Novovjekovne zbirke arheološkog muzeja Istre, Histria archaeologica 43, 2012., 181., kat. 27.

36 Z. NAGY, n.dj., 46-50; D. GAČIĆ, n.dj., 34.

37 Hrvatska; B. MILOŠEVIĆ, N. TOPIĆ, Keramičke lule s lokaliteta Kula Gornji ugao u Dubrovniku, 306-307; Slovačka; M. BIELICH, M. ČURNY, n.dj., 345-347. 
u obliku školjke i dio kružne čašice, a na drugoj kat. 16, samo tuljac. Nemamo izravnih analogija za ove lule, ali ih prema obliku možemo pripisati nekoj od radionica koje su imitirale izgled lula iz Banske Štiavnice. ${ }^{38}$ Okvirno ih se može datirati u 19. st. Lula kat. 17 (T.III-17), specifičnog je izgleda. Izrađena je od gline crvene boje. Greben joj je zadebljan u odnosu na tuljac. Kroz lulu ide jedna vezna rupa. Baza čašice dvostruko je profilirana s prstenastim prepletom, a gornji dio je izveden reljefnim trokutovima, koji su nasuprotno postavljeni. Čitava čašica je premazana bijelom glinom, te su pojedini djelovi tirkizno bojani. Obruč je malo odvojen od ruba tuljca, ukrašen gustim mrežastim motivom. Na tuljcu se nalazi pravokutni pečat s natpisom LSLESINGER (T. VII-29), a s desne strane tog pečata je mali pečat u obliku medaljona s nečitljivim motivom. Po otvoru rupe tuljca je natpis PIPA ili možda PAPA?, omeđen s po dvije vitice, a s druge strane su slova IGAZ? (T. VII-28). Čitava je vanjska površina lule glazirana. Iako nema izravnih analogija, prema pečatu je vezujemo uz radionicu Lipóta Schlesingera. ${ }^{39}$ Specifičan oblik grebena i čašice, mješavina je oblika karakterističnih za austrijske, ali i mađarske radionice. Ovo bi se moglo objasniti činjenicom da je veći broj radionica koje vuku podrijetlo iz Austrije tokom 19. st., preselilo u Bansku Šitavnicu, a zatim i u Mađarsku, tj. gradove Körmend i Vasvár. ${ }^{40}$ Jedina lula u Hrvatskoj koju bi zasad mogli povezati s ovom, nađena je na lokalitetu Zoljani-Čemešac I. Ima pečat sa istim majstorom ali prema obliku nije slična primjerku iz Varaždina. ${ }^{41}$ Što se tiče datacije, proizvodi iz ove radionice se datiraju u drugu polovicu 19. st., ${ }^{42}$ pa bi prema tome tako trebalo datirati i ovu lulu. Primjerci kat. 18, 19, 20 (T.III-18-20) zastupaju produkciju austrijskih radionica iz okolice Beča. Poznate su one iz Theresienfelda, Wiener Neustadta i Pernitza. Jedino je luli kat. 18 iz ove grupe, bilo moguće odrediti točnu radionicu i majstora prema pečatu. U ovom slučaju to je Joseph Partsch, iz Theresienfelda. Izrađena je u kalupu sa crvenkasto pečenom bojom gline, zaglađena joj je površina, koja nije glazirana. Gornji dio čašice je kružan, a baza je izvedena reljefno u obliku latica sa lagano zadeblja-

38 Radionice imitacija su obradili Mario BIELICH i Marian ČURNY; M. BIELICH, M. ČURNY, n.dj., 348,349 .

39 Ova radionica je bila poznata po izradi imitacija lula iz Banske Štiavnice, ali još nije točno određen grad u kojem je bila smještena. Pretpostavlja se da je to neki od ranije spomenutih mađarskih gradova; Z. NAGY, n.dj., 47; M. BIELICH, M. ČURNY, n.dj., 348. Grad u kojem se nalazi ova radionica, zbog natpisa na rubu obruča, možemo možda smjestiti u grad Pápa, koji se nalazi u sjevero-zapadnoj Mađarskoj, blizu granice sa Slovačkom.

40 Z. NAGY, n.dj., 50; M. BIELICH, M. ČURNY, n.dj., 351.

${ }^{41}$ Natpis je CHLESINGER SCHEMNITZ; M. ŠIŠA-VIVEK, K. FILIPEC, n.dj., 328, kat. 38.

42 M. BIELICH, M. ČURNY, n.dj., 348. 
nim grebenom. Vanjska ploha obruča ukrašena je mrežastim motivom, dok je na otvoru tuljca utisnuto *ZU*THERESIENFELD (T. VII-31). ${ }^{43} \mathrm{Na}$ tuljcu također ima i trapezasti pečat s natpisom IOS. PARTSCH (T. VII-30). Jednu vezna rupa ide kroz tijelo. Izravnih analogija za ovu lulu zasada nemamo, ali izradom i oblikom istih karakteristika je lula nađena u Zadru, iz radionice A. Ressa, koja je također djelovala u Austriji, i to u Wiener Neustadtu. ${ }^{44}$ Prema preciznoj dataciji djelovanja lularske radionice Josepha Partscha, 40-tih. god. 19. st., ${ }^{45}$ ovu lulu treba upravo tako datirati. Sljedeća, kat. 19 je istih karakteristika kao prethodno opisana, uz razliku u pečatu, koji je u ovom slučaju okrugli s inicijalima IT? ili JT? Do njega je još jedan sa oznakom 80 (T. VII-23). Na tuljcu je dodano prstenasto rebro. Prema do sada objavljenim analogijama se još uvijek nemože točno odrediti o kojoj se radionici ovdje radi, ali se sa velikom sigurnošću ovu lulu može pripisati austrijskom radioničkom krugu. Datira se isto kao i prethodno opisana, zbog velike međusobne sličnosti. Upravo stoga ne toga isključiti i mogućnost da dolaze iz iste radionice. Na ovu grupu, tj. produkciju, se vezuje i lula kat. 20. Izrađena je u kalupu, od crvene gline, a oblikom vuče paralele sa prethodno opisanim iz ove grupe. Ova lula ima i jednu posebnost, naime, na gornjem dijelu čašice su izvedeni floralni motivi (cvijet i listovi), bojani na crvenoj podlozi bijelom i zelenom bojom (T. VII-25). Također ima i ostatak stopice za naslanjanje na dnu čašice. Zbog nedostatka analogija, datiramo je okvirno u 19. st. Još jedan manji fragment bi mogli pripisati ovoj produkciji, lulu kat. 21. Sačuvan je samo dio tuljca s malim obručem. Nema nikakvih ukrasa, a lula je izrađena od crveno-žute gline, u kalupu. Zbog nedostatka izravnih analogija nije moguća točna datacija, ali ako uzmemo u obzir da je jako malih dimenzija, možemo je okvirno datirati u 18. st. Dvije lule kat. 22 i 23 (T.IV-22, 23) također nije bilo moguće pobliže radionički determinirati, a sačuvani su im samo tuljci s obručima. Lula kat. 23, izrađena je od sive gline, dok je lula kat. 22 izrađena od žućkaste gline, obje u kalupu sa jednom veznom rupom. Ispod otvora oba tuljca su dva reljefna rebra, a na luli kat. 22 je ono bliže otvoru tuljca ukrašeno i kosim crticama. Na luli kat. 23 je uočljiv nečitki pravokutni pečat sa oštećenim gornjim redom, dok se u donjem nadzire natpis SCHEMNITZ (T. VI-21). O točnim radionicama u kojima su ove lule proizvedene je zbog manjka analogija teško govoriti, ali ih prema obliku i

43 Lula sa pečatom Theresienfeld na vanjskom dijelu otvora tuljca, je nađena i u Dubrovniku. Ona ima pečat sa drugim proizvođačem; B. MILOŠEVIĆ, N. TOPIĆ, Nalazi keramičkih lula s lokaliteta Sv. Marija od Kaštela i Posat od Ploča u Dubrovniku, 261, 265, sl. 1, T 3-1, 1a.

44 K. GUSAR, n. dj., 143, 144, kat. 8, T. 3, 2.

45 Radionica Josepha Partscha, je djelovala oko 1842. god.; Z. NAGY, n.dj. 49; M. BIELICH, M. ČURNY, n.dj., 352. 
načinu izrade vezujemo uz austrijski ili mađarski radionički krug austrugarskog tipa lula, te ih okvirno datiramo u 18.-19. st. ${ }^{46}$

Slovačkom radioničkom centru iz Podrečanya pripada lula kat. 24 (T.IV-24), koja je karakterističan primjerak proizvoda te radionice. Sive je boje gline, izrađena je u kalupu i crno pečena, s jednom veznom rupom. Sačuvao joj se samo tuljac. Obruč nije ukrašen, a do njega je prstenasto rebro. S donje strane tuljca je zadebljanje u obliku rebra, a na tuljcu je i ovalni pečat s natpisom PODRECS (T. VII-26). S druge strane je kružni, bordurom ukrašen pečat s inicijalima JK ili JH? (T. VII-27). ${ }^{47}$ Prema analognim primjercima iz Češke i Hrvatske datiramo je u kraj 18. st. početak 19. st. ${ }^{48}$

Sljedeća veća grupa unutar austro-ugarskog tipa koju možemo izdvojiti su tzv. kavanske lule. Masovno su se proizvodile u drugoj polovini 19. st., kada u Europu "ulazi" moda ispijanja kave u kavana. Uz običaj ispijanja kava, pušenje lule je bio sastavni dio te mode. Brojne kavane su ovakve lule dijelile kao dar gostima, jer su pripadale kategoriji robe široke potrošnje. Bile su izuzetno popularne u Češkoj, Austriji te južnoj Njemačkoj, a uvriježio se i naziv "Kaffeehaus" ili Coffehouse". Zasad poznate radionice ovog tipa bile su u gradu Beču (Meidling), njemačkom gradu Kölnu te češkom Kolinu. Dvodjelne su to lule izrađivane u kalupu, od bijele kaolinske gline. Ukrasi su bili vitičasti i mrežasti, često sa nat-

46 L. BEKIĆ, Uvod u problematiku glinenih lula na području, 252; ; M. VYŠOHLID, Clay Tobacco Pipes in Bohemia, 20-22 M. VYŠOHLID, Keramické dýmky v archeologických nálezech a jejich vypovídací možnosti, Clay tobacco pipes in the archaeological finds and their ability to testify, 988, 989; Gačić, n.dj., 34; E, ZEJNILHODŽIĆ, n.dj., 168.

47 Proizvodni centar ovih lula smješta se u južno slovačko naselje Podrečany blizu grada Lučene, a u blizini granice Slovačke i Mađarskom. Za ovu radionicu je karakteristično pojavljivanje ovalnih pečata s natpisom, koji izgledom posjeća na rukopis. Pečat je najčešći Podrecs, dok još mogu biti PODREC, PODRES, PODRECZ, PODRETS, prema analogijama iz Slovačke i Češke. Zanimljiv je i kružni pečat uokviren prepletenim lišćem s inicijalima JH ili JK, koji se nalazi sa druge strane tuljca. On bi mogao označavati majstora, koji je započeo proizvodnju lula u Podrečanyu - JURAJ KRČIAŠKO; Martin VYŠOHLID,Clay Tobacco Pipes in Bohemia, Journal of the Académie Internationale de la Pipe, Vol. 2, 2009, 20, 21; M. VYŠOHLID, Keramické dýmky v archeologických nálezech a jejich vypovídací možnosti, Clay tobacco pipes in the archaeological finds and their ability to testify, 988, 989; M. BIELICH, M. ČURNY, n.dj. 350, 351; Vladimir MITAŠ, Zuzana POLAKOVA., Keramické fajky z archeologických nálezísk Gemera-Malohontu a Novohradu, Zbornik Gemerskomalohontskeho muzea v Rimavskej Sobote, ročnik 11, 2015, 70-73; L. BEKIĆ, Duhanske lule iz nekadašnje vojarne sv. Nikola u Zadru, 139. Zanimljivo je da danas ovo slovačko mjesto u svome grbu, uz klas pšenice, ima i prikazanu lulu; www.podrecany.sk (25. 8. 2018.)

48 Za analogiju iz Češke; M. VYŠOHLID, Clay tobacco pipes in Bohemia, 22, fig. 5; Za analogiju iz Hrvatske sa lokaliteta Zoljani - Čemešac I, M. ŠIŠA-VIVEK, K.FILIPEC, 330, kat. 27; s lokaliteta Sv. Nikola u Zadru; L. BEKIĆ, Duhanske lule iz nekadašnje vojarne sv. Nikola u Zadru, 139, 140, sl. 2 , kat. 2. 
pisom CAFÉ i nazivom radionice. Kroz lulu je išla jedna ili nekad i dvije vezne rupe. ${ }^{49}$ Šest je primjeraka ovih karakteristika u našoj zbirci, kat. 25-30 (T.IV-2530). Zastupljene su sve ranije spomenute radionice. Četiri pripadaju radionicama iz Kolina; kat. 27-30, jedna je iz Kölna kat. 26, a jedna iz Beča- Meidling; kat. 25. Lule koje pripadaju radionici iz češkog grada Kolina su ukrašene reljefnom mrežom, unutar koje su točkice (T. V-11). Ovakvim ukrasom je prekrivena čitava površina čašice i obruča. To je slučaj na primjercima kat. 27, 28, 29, 30. Vitičasti ukras je također česta pojava kod ove radionice (T. V-10). Vidimo to na primjerku kat. 27. Osim toga ovaj primjerak ima i glatki obruč, bez ukrasa, a kroz tuljac prolazi jedna vezna rupa. Radionice iz njemačkog grada Kölna su zastupljene sa primjerkom kat. 26. Ova lula izrađena je u kalupu, od bijele gline sa crvenim premazom i ima dvije vezne rupe. Obruč je naglašen, s vitičastim motivima. Tuljac je signiran natpisom CÖLN (T.V-6), a s druge strane CAF(E) (T. V-7). Zadnja iz ove grupe je lula kat. 25. Prepoznatljiva je po natpisu MEIDLING (T. V-4) na tuljcu, a sa suprotne strane je oznaka SS (T. V-5), koja možda označava majstora. Izrađena je u kalupu sa dekoriranim obručem. Ukrašena je sa vitičastim, i u obliku sukane uzice izvedenim motivima. Analogije za ovakav tip lula imamo sa lokaliteta Hainburg na Dunavu u Austriji, te iz grada Praga. ${ }^{50}$ U Srbiji je također otkriveno više analognih primjeraka. ${ }^{51}$ Što se tiče Hrvatske, dva primjerka su nađena u Dubrovniku, od toga jedan sa natpisom CAFÉ CÖLN. Datiraju se u drugu pol. 19. st. ${ }^{52}$ Sve lule iz ove grupe stoga prema analognim primjercima datiramo u navedeno razdoblje.

49 Luka Bekić navodi da se na austrougarskim lulama u 19. st. često nalaze mjedeni poklopci za čašicu, te da se to naziva "Coffehouse" stil.; L. BEKIĆ, Uvod u problematiku glinenih lula na području Hrvatske, 252; M. VYŠOHLID, Clay Tobacco Pipes in Bohemia, 20; Martin VYŠOHLID, Dymky z Archeologickeho vyzkumu v Dolnorakovskem meste Hainburg an der Donau, Historia vyroby fajok a archeologicke nalezy fajok na Slovensku II, Tekovske Muzeum v Leviciach, 2016, 6, 7; Michal PREUSZ, Novověké dýmky v jižních Čechách : Nálezy ze sbírky Jihočeského muzea v Českých Budějovicích, Archeologické výzkumy v jižních Čechách 29, 2016., 401.

50 M. VYŠOHLID, Dymky z Archeologickeho vyzkumu v Dolnorakovskem meste Hainburg an der Donau, 6, 7, 10, Obr.č. 3-4, 5, 6; M. VYŠOHLID, Keramické dýmky v archeologických nálezech a jejich vypovídací možnosti, Clay tobacco pipes in the archaeological finds and their ability to testify, 983-985, obr. 21-c, d, obr. 22.

51 D. GAČIĆ, n. dj., 134-134, kat. 205-209.

52 B. MILOŠEVIĆ, N. TOPIĆ, Keramičke lule s lokaliteta Kula Gornji ugao u Dubrovniku, 314, sl. 43, 43a; B. MILOŠEVIĆ, N. TOPIĆ, Nalazi keramičkih lula s lokaliteta Sv. Marija od Kaštela i Posat od Ploča u Dubrovniku, 265-266, T 3-3, 3a. 


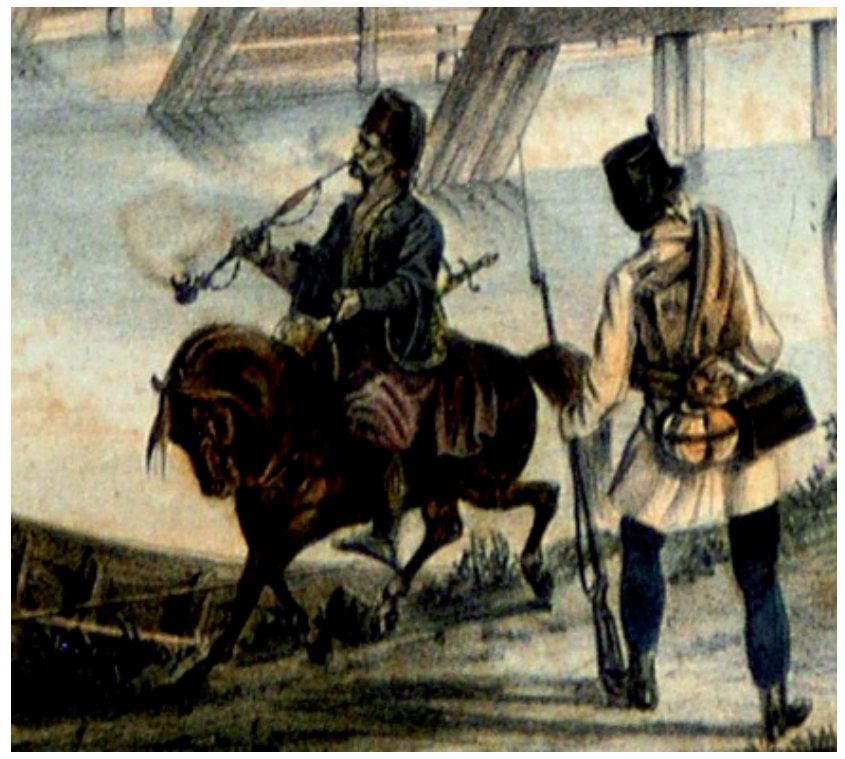

Slika 2. Isječak iz kolorirane litografije, Prikaz pandura na konju kako puši lulu istočnog tipa - Prijelaz hrvatske vojske preko Drave kod Varaždina, 11. rujna

1848. god. Autor F. Zalder, Beč, 1850. god. Inventarni broj: GMV 43118

\section{ZAKLJUČNA RAZMATRANJA}

Zbirka glinenih lula koja je u fokusu ovog rada, sastoji se uglavnom od primjeraka nađenih unutar gradske jezgre Varaždina, njih dvadest i sedam. Prilikom arheoloških istraživanja prostora varaždinskog Starog grada tokom projekta Bastion, ${ }^{53}$ pronađena je upravo najveća skupina ovih predmeta. Indikativno je da su, prema dokumentaciji arheoloških iskopavanja, ${ }^{54}$ sve lule pronađene u sjevernom mokrom grabištu i to $u$ jednoj sondi tj. njezinom produžetku. U dubljim slojevima pronađene su dvije turske lule koje se datiraju u kraj 17. st., te jedna lula zapadnog tipa iste datacije. U plićim slojevima otkriveno je deset lula austro-

53 Neke od lula su objavljene u katalogu izložbe koja je tematizirala prije spomenuta arheološka istraživanja, vidi u; Spomenka TEŽAK, Miroslav KLEMM, Marina ŠIMEK, Iz srednjega u novi vijek: Varaždinski Stari grad i projekt Bastion, Katalog izložbe, Gradski muzej Varaždin, Varaždin, 2008.

54 Dokumentacija o ovom istraživanju čuva se u Gradskom muzeju Varaždin, na Arheološkom odjelu. 
ugarskog tipa tj. kavanskog podtipa, koje možemo datirati u 18. i 19. st. ${ }^{55}$ Prilikom arheoloških istraživanja u blizini crkve Sv. Florijana te Vodnikovoj ulici, ${ }^{56}$ koja se nalazi nasuprot sjevernog bedema varaždinskog Starog grada, otkriveno je jedanaest primjeraka lula koje se mogu svrstati u istu kategoriju kao i prethodno spomenute. Još dvije lule austrougarskog tipa pronađene su u Varaždinu, i to u Preradovićevoj ulici. Spomenute lule iz Vodnikove ulice ali i ona iz okolice crkve Sv. Florijana, kavanskog podtipa, možemo vezati uz temu varaždinskih kavana. Naime, lule iz Vodnikove pronađene su sve u istoj sondi i stratigrafskog jedinici, stoga ih se može približno precizno datirati u drugu polovinu 19. st., tj. vrijeme funkcioniranja kavane „K zlatnom lavu“, koja se nalazila uz sjeverno grabište tvrđave, tj. $u$ današnjoj ulici Vladimira Nazora, nedaleko mjesta gdje su pronađene. I u Preradovićevoj se nalazila gostionica, zvana "Graczka pivnica“". Između ovih kavana i lula stoga je moguće povući paralele, jer se radi o karakterističnom tipu lula, kakve su se koristile na takvim mjestima. Iz svega navedenoga razvidno je kako je sjeverni bedem varaždinskog Starog grada, ali i prostor oko njega, bio mjesto okupljanja pušača. U 17. st. to su mogli biti stražari, a u 18. i 19. st., vjerojatno, šetači. Nije nemoguće zamisliti kako su svi navedeni dotrajale lule jednostavno bacili preko bedema (kao danas opušak), te posegnuli za novom. Osim ovih varaždinskih, u muzeju se čuva i jedna lula iz samostanskog kompleksa u Lepoglavi. Pronađena je u sloju recentnog zasipa, pa je time njen interpretativan potencijal bitno umanjen, međutim bez obzira na to ona svakako doprinosi dobivanju šire slike o distribuciji i tipovima lula kakve su se koristile na prostoru Varaždinske županije. Kada se sve ove lule tipološki usporede s pronađenim na drugim lokalitetima, primjerice u nedalekom Ivancu, ${ }^{58}$ ali i Češkoj, Slovačkoj, Sloveniji te Mađarskoj, vidimo da je ovaj naš uzorak tipološki gotovo identičan onom u zemljama sjevernog okruženja.

To nam govori u prilog koliko je prostor Varaždinske županije bio usko povezan s prostorom centralne Europe, posebice u 18 i 19. st. Dvije glinene lule

55 U dokumentaciji sa ovog istraživanja se nigdje izrijekom ne govori o zatvorenoj nalaznoj cijelini u kojoj bi ovi predmeti bili nađeni, ali svakako možemo govoriti o stratigrafski mlađim i starijim slojevima u kojima su nađene ove lule.

56 Izvještaji o ovim zaštitnim arheološkim istraživanjima se nalazi $u$ arhivi dokumentacije Arheološkog odjela GMV-a.

57 Ivy LENTIĆ-KUGLI, Prilog istraživanju varaždinskih svratišta, gostiona i kavana u 18. st. i prvoj polovini 19. st., Godišnjak Gradskog muzeja Varaždin 5, 1975, 55-57., Izvještaj o arheološkom nadzoru u Vodnikovoj ulici se nalazi u arhivi Arheološkog odjela Gradskog muzeja Varaždin.

58 Objavljeno je 5 lula sa istaživanja Starog grada Ivanca, Austrougarskog i turskog tipa; J. BELAJ, n. dj., 15, sl. 23. 
su pronađene i u špilji Vindija. ${ }^{59} \mathrm{U}$ muzej su dospjele zajedno s predmetima iz ostavštine S. Vukovića. Tipične su za razdoblje samog početka pušenja u ovom dijelu Europe, u drugoj pol. 17. st. Prema ovim nalazima možemo zaključiti da se u špilji skrivalo, a možda i duže boravilo, tijekom ranog novoga vijeka, odnosno u vrijeme opasnosti od osmanlijskih upada. Kako su spomenute lule tipičnog turskog tj. krajiškog podrijetla, nameće se još jedna mogućnost; u špilji Vindiji vjerojatno su boravili vojnici. Mogli su to biti domaći graničari ili možda osmanlijski vojnici, koji su špilju mogli koristili kao privremeno sklonište, a pušenjem su kratili vrijeme. Zanimljivo je ovdje povući paralelu i sa prikazima vojnika na grafikama iz 19. st. Naime vojnici ${ }^{60}$ su često bili prikazivani upravo kako puše lule, pa se tako i u Gradskom muzeju Varaždin čuvaju dvije grafike sa prikazima vojnika tj., pandura sa lulama istočne skupine, s dugim kamišima. (vidi sl. 2. i 3.). Lule iz Vindije, ali i one sa varaždinskog Starog grada turskog tipa-krajiškog podtipa, govore nam u prilog osmanlijskog utjecaja tokom 17. i 18. st. na život u ovim krajevima. Na kraju bi spomenuo i jednu pomalo bizarnu paralelu Varaždina i glinenih lula. Naime, radi se o priči o velikom požaru koji je zahvatio Varaždin u proljeće 1776. god. Požar je to koji je ostao zapamćen kao prekretnica u razvoju Varaždina, jer tada gubi status glavnog grada. Okosnica priče je dječak iz Sračinca, naselja nedaleko Varaždina, koji se pušeći spotaknuo i žarom zapalio slamu te tako izazvao požar, koji se ubrzo proširio gradom. ${ }^{61}$ Iako se nigdje ne spominje, vjerojatno je pušio baš glinenu lulu. ${ }^{62}$ Iz ove priče vidimo kako jedan, naoko, mali predmet može utjecati na značajan događaj u povijesti neke zajednice, u ovom slučaju grada Varaždina.

59 Dokumentacija o istraživanjima špilje Vindija se čuva u Arheološkom odjelu, Gradskog muzeja Varaždin. Dugogodišnja istraživanja je vodio kustos GMV-a, Stjepan Vuković. Iako istraživač koji je bio zaokupljen prapovijesnim slojevima špilje Vindija, Stjepan Vuković je uz mnoštvo prapovijesnih nalaza, pedantnošću istraživača, prikupio i ove dvije ranonovovjekovne lule turskoga tipa, premda one nisu bile u fokusu interesa tadašnjih arheologa. Stoga ih i nije valorizirao unutar priče o ovom lokalitetu, ali ih je ipak sačuvao.

60 Upravo su vojnici u razdoblju od 17.-19. st. poznata populacija pušača; Luka BEKIĆ, Duhanske lule iz nekadašnje vojarne sv. Nikola u Zadru, 137.

61 Hrvoje PETRIĆ, O požarima i urbanom okolišu slobodnih kraljevskih gradova Hrvatsko-Slavonskog kraljevstva u ranom novom vijeku (Varaždin, Križevci, Koprivnica, Zagreb). Ekonomska $i$ ekohistorija: Časopis za gospodarsku povijest i povijest okoliša 5, 2009., 167.

62 Do poč. 20. st. u Europi se nisu se pušile cigarete već samo lule, a u 18. i 19. st. posebno su bile popularne one keramičke; R. C. W. ROBINSON, n. dj., 152. 


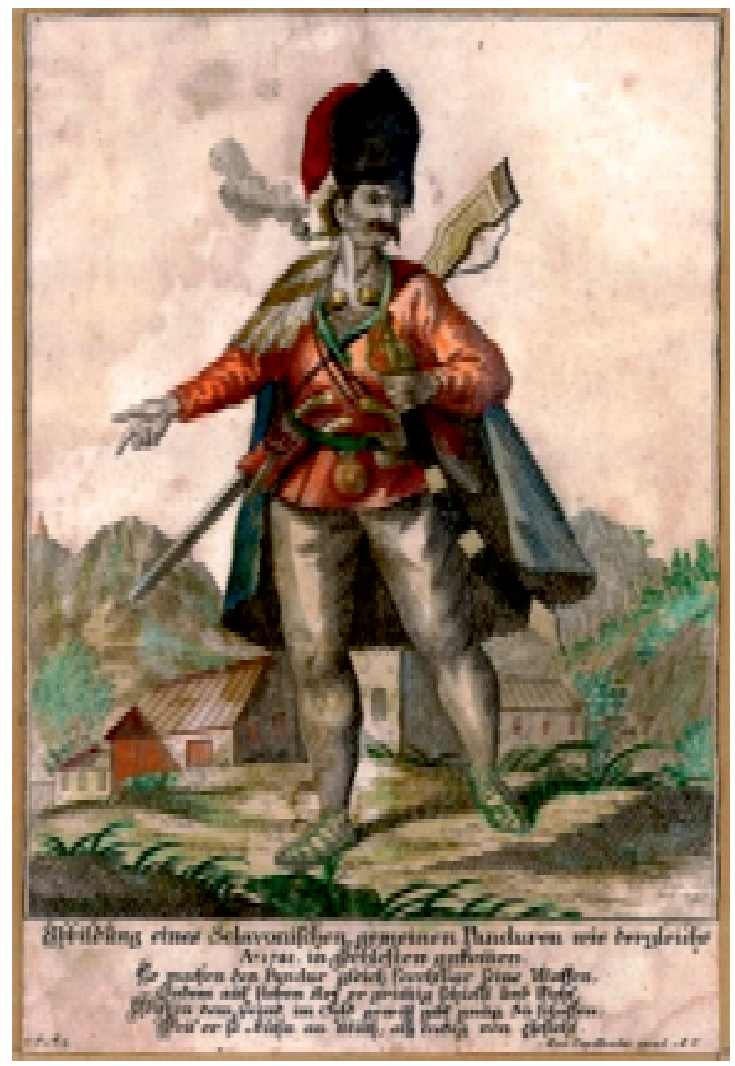

Slika 3. Grafika s prikazom Slavonskog pandura s lulom, 1741. god. Inv. br. GMV KPO 7834 


\section{KATALOG}

P. P. D. = promjer prostora za duhan; U. P. T. = unutrašnji promjer tuljca; D. S. Č. = debljina stijenke čašice; V. P. D. = visina prostora za duhan; (N. S.) V. = (najveća sačuvana) visina lule, GMV=Gradski muzej Varaždin, Vž.=Varaždin, arheo. istraž.= arheološko istraživanje, Z. gr. arheo.=Zbirka gradske arheologije, Z. nv. g.=zbirka novovjekovne građe, S.J.=stratigrafska jedinica.

1. Lula, dimenzije: P. P. D. $=1,9 \mathrm{~cm}$; D.S.Č $=0,3 \mathrm{~cm}$; (N. S.) V. $=3,7 \mathrm{~cm}$

Zbirka i inventarni broj: Z. gr. arheo., GMV-88735

Nalazište: Vž. Stari grad, M. Šimek, arheo. istraž., 2006., god., S-Z ugao mokrog jarka, sonda/blok: XVII.

Tip: Zapadni, njemački? Neobjavljeno.

2. Lula, dimenzije: P. P. D. $=1,5 \mathrm{~cm}$, U. P. T. $=0,7 \mathrm{~cm}$, V. P. D. $=2,8 \mathrm{~cm}$, D. S. Č. $=0,3 \mathrm{~cm}$, (N. S.) V.=3,1cm.

Zbirka i inventarni broj: Z. gr. arheo., GMV-88715

Nalazište: Vž. Stari grad, ${ }^{63}$ M. Šimek, arheo. istraž., 2006., Sonda/blok: S.VII A?, S.J.017, 020, 024?

Tip: Istočni, turski, krajiški. Neobjavljeno.

3. Lula, dimenzije: P. P. D. $=1,8 \mathrm{~cm}$, U. P. T. $=0,9 \mathrm{~cm}$, D. S. Č. $=0,3 \mathrm{~cm}$, (N. S.) V. $=3,4 \mathrm{~cm}$. Zbirka i inventarni broj: Z. gr. arheo., GMV-53237.

Nalazište: Vž. Stari grad, M. Šimek, arheo. istraž., 2006., sjeverno unutarnje grabište, sonda/blok: S.VIIA, S.J.013A

Tip: Istočni, turski, krajiški. Objavljeno. ${ }^{64}$

4. Lula, dimenzije: P. P. D. $=1,8 \mathrm{~cm}$, U. P. T. $=0,9 \mathrm{~cm}$, D. S. Č. $=0,3 \mathrm{~cm}$, (N. S.) V. $=3,6 \mathrm{~cm}$. Zbirka i inventarni broj: Z. nv. g., GMV- 88747.

Nalazište: Špilja Vindija ${ }^{65}$

Tip: Istočni, turski, krajiški. Neobjavljeno.

63 Napomena: prilikom pregleda građe ova je lula nađena u kutiji izdvojena od ostalog materijala nađenog u istraživanju Starog grada 2006. god. u projektu Bastion. U kutiji je bila signatura, navedena u rubrikama zajedno s metalnim nalazima (puščana zrna) i staklenim predmetima.

64 Težak, S.; Klemm, M.; Šimek, M., n. dj., str. 41. kat. br. 67.

65 Napomena: Lula je pronađena u kutiji zajedno s ostalim materijalom iz špilje Vindije, bez podataka o godini iskopavanja ili kontekstu. Na kutiji je pisalo "Predmeti iz Vindije - poklon Z. Vuković". 
5. Lula, dimenzije: U. P. T. $=0,4 \mathrm{~cm}$, (N. S.) V. $=1,8 \mathrm{~cm}$

Zbirka i inventarni broj: Z. nv. g., GMV- 88748 .

Nalazište: Špilja Vindija. ${ }^{66}$

Tip: Istočni, turski, krajiški. Neobjavljeno.

6. Lula, dimenzije: P. P. D. $=1,3 \mathrm{~cm}$, U. P. T. $=1,2 \mathrm{~cm}$, D. S. Č $=0,3 \mathrm{~cm}$, (N. S.) V.=3,5cm Zbirka i inventarni broj: Z. gr. arheo., GMV- 53243.

Nalazište: Vž. Stari grad, M. Šimek, arheo. istraž.. 2006., položaj: sjeverno unutarnje grabište, sonda/blok: S.VIIA, E - profil.

Tip: Istočni, turski, krajiški. Neobjavljeno.

7. Lula, dimenzije: P. P. D. $=1,9 \mathrm{~cm}$, U. P. T. $=1,2 \mathrm{~cm}$, D. S. Č $=0,3 \mathrm{~cm}$, (N. S.) V. $=3,9 \mathrm{~cm}$ Zbirka i inventarni broj: Z. gr. arheo., GMV-88723.

Nalazište: Vž., Vodnikova ul., M. Jurišić, zaštit. arheo. iskop. 2007. god.; sonda/ blok: S.II, S.J.016.

Tip: Istočni, austrougarski, Schemnitz, Michal Hönig. Neobjavljeno.

8. Lula, dimenzije: P. P. D. $=1,9 \mathrm{~cm}$, U. P. T. $=1,2 \mathrm{~cm}$, D. S. Č $=0,3 \mathrm{~cm}$, (N. S.) V. $=2,9 \mathrm{~cm}$ Zbirka i inventarni broj: Z. gr. arheo., GMV-88722

Nalazište: Vž., Vodnikova ul., M. Jurišić, zaštit. arheo. iskop., 2007. god.; sonda/ blok: S.II, S.J.016.

Tip: Istočni, austrougarski, Schemnitz, Michal Hönig. Neobjavljeno.

9. Lula, dimenzije: P. P. D. $=1,8 \mathrm{~cm}$, U. P. T. $=1,2 \mathrm{~cm}$, D. S. Č. $=0,3 \mathrm{~cm}$, (N. S.) V.=3,7cm Zbirka i inventarni broj: Z. gr. arheo., GMV-88720

Nalazište: Vž., Vodnikova ul., M. Jurišić, zaštit. arheo. iskop., 2007. god.; sonda/ blok: S.II, S.J.016

Tip: Istočni, austrougarski, Schemnitz, Neobjavljeno.

10. Lula, dimenzije: P. P. D. $=1,8 \mathrm{~cm}$, U. P. T. $=1,2 \mathrm{~cm}$, D. S. Č. $=0,3 \mathrm{~cm}$, (N. S.) V. $=3,4 \mathrm{~cm}$ Zbirka i inventarni broj: Z. nv. g. GMV-88738

Mjesto nalaza: Nepoznato.

Tip: Istočni, austrougarski, Schemnitz. Neobjavljeno.

11. Lula sa metalnim poklopcem.

Dimenzije: P. P. D. $=2 \mathrm{~cm}$, U. P. T. $=1,2 \mathrm{~cm}$, D. S. Č $.=0,3 \mathrm{~cm}$, V. P. D. $=5,7 \mathrm{~cm},($ N. S.) $\mathrm{V} .=7,3 \mathrm{~cm}$

Zbirka i inventarni broj: Z. nv. g., GMV-84775-lula, poklopac- GMV-84776.

66 Isto kao fusnota 64. 
Nalazište: Lepoglava, Pleše Tajana, arheo. iskop. 2004. god., ${ }^{67}$ sjeverni dio zapadnog samostanskog krila; sloj: zasip.

Tip: Istočni, austrougarski, Schemnitz, Michal Hönig. Neobjavljeno.

12. Lula, dimenzije: P. P. D. $=1,8 \mathrm{~cm}$, U. P. T. $=1,2 \mathrm{~cm}$, D. S. Č. $=0,4 \mathrm{~cm}$, (N. S.) V. $=5,9 \mathrm{~cm}$ Zbirka i inventarni broj: Z. gr. arheo. GMV-53239

Nalazište: Vž. Stari grad, M. Šimek, arheo. iskop., sjeverno unutarnje grabište, sonda/blok: S.VII, S.J.008.

Tip: Istočni, austrougarski, imitacija Schemnitz lule. Objavljeno. ${ }^{68}$

13. Lula, dimenzije: P. P. D. $=2 \mathrm{~cm}$, U. P. T. $=1,5 \mathrm{~cm}$, D. S. Č. $=0,4 \mathrm{~cm}$, (N. S.) V. $=5,7 \mathrm{~cm}$ Zbirka i inventarni broj: Z. gr. arheo., GMV-53240.

Nalazište: Vž. Stari grad, M. Šimek, arheo. iskop., 2006. god., sjeverno unutarnje grabište, sonda/blok: S.VIIA, S.J.013A.

Tip: Istočni, austrougarski, Bodnar. Objavljeno. ${ }^{69}$

14. Lula, dimenzije: P. P. D. $=2 \mathrm{~cm}$, U. P. T. $=1,5 \mathrm{~cm}$, D. S. Č. $=0,4 \mathrm{~cm}$, (N. S.) V.=5,7cm Zbirka i inventarni broj: Z. gr. arheo., GMV-88721

Nalazište: Vž., Vodnikova ul., M. Jurišić, zaštit. arheo. iskop., 2007. god.; sonda/ blok: S.II, S.J.016.

Tip: Istočni, austrougarski, Leopold Gross. Neobjavljeno.

15. Lula, dimenzije: P. P. D. $=1,4 \mathrm{~cm}$, U. P. T. $=1,1 \mathrm{~cm}$, D. S. Č $=0,2 \mathrm{~cm}$, (N. S.) V. $=3,8 \mathrm{~cm}$ Zbirka i inventarni broj: Z. gr. arheo., GMV-43837

Nalazište: Vž. Stari grad, M. Šimek, arheo. iskop., 2006. god.; sjeverno grabište, sonda/blok: S.VII, dubina: $60 \mathrm{~cm}$, S.J.011.

Tip: Istočni, austrougarski. Neobjavljeno.

16. Lula, dimenzije: U. P. T. $=1,1 \mathrm{~cm}$, (N. S.) V. $=2,1 \mathrm{~cm}$

Zbirka i inventarni broj: Z. gr. arheo., GMV-88718

Nalazište: Vž., Preradovićeva 14, M. Korunek, zaštit. arheo. iskop., 2007. god., sonda/blok: S. I, S.J.: 1, sloj: recentni nasip.

Tip: Istočni, austrougarski. Neobjavljeno.

17. Lula, dimenzije: P. P. D. $=1,7 \mathrm{~cm}$, U. P. T. $=1,3 \mathrm{~cm}$, D. S. Č. $=0,3 \mathrm{~cm}$, (N. S.) V. $=4,1 \mathrm{~cm}$ Zbirka i inventarni broj: Z. gr. arheo., GMV-88724

Nalazište: Vž., Vodnikova ul., M. Jurišić, zaštit. arheo. iskop., 2007. god., sonda/

67 Dokumentacija Ao GMV-a.

68 S. TEŽAK, M. KLEMM, M. ŠIMEK, n. dj., 42, kat. 70.

69 S. TEŽAK, M. KLEMM, M. ŠIMEK, n. dj., 42, kat. 69. 
blok: S.II, S.J.016.

Tip: Istočni, austrougarski, Papa, Lipót Schlesinger. Neobjavljeno.

18. Lula, dimenzije: P. P. D. $=1,3 \mathrm{~cm}$, U. P. T. $=1,2 \mathrm{~cm}$, D. S. Č. $=0,3 \mathrm{~cm}$, (N. S.) V. $=3,4 \mathrm{~cm}$ Zbirka i inventarni broj: Z. gr. arheo., GMV-94594

Mjesto nalaza: Vž., ul. Ivana Padovca 6, M. Grgurić, arheo. nadzor, 2012. god., granica sektora I i II, tj. na sredini iskopa, S.J. 02/05, 70-ak cm dubine.

Tip: Istočni, austrougarski, Theresienfeld, Joseph Partsch. Neobjavljeno.

19. Lula, dimenzije: P. P. D. $=1,4 \mathrm{~cm}$, U. P. T. $=1 \mathrm{~cm}$, D. S. Č $=0,3 \mathrm{~cm}$, (N. S.) V.=3,2cm Zbirka i inventarni broj: Z. gr. arheo., GMV- 43835

Nalazište: Vž. Stari grad, M. Šimek, arheo. iskop., 2006. god.; sjeverno unutarnje grabište, sonda/blok: S.VII, dubina: $60 \mathrm{~cm}$, S.J.011

Tip: Istočni, austrougarski, Austrija. Neobjavljeno.

20. Lula, dimenzije: P. P. D. $=1,5 \mathrm{~cm}$, D. S. Č $=0,3 \mathrm{~cm}$, (N. S.) V. $=4,5 \mathrm{~cm}$

Zbirka i inventarni broj: Z. gr. arheo, GMV-53244

Nalazište: Vž. Stari grad, M. Šimek, arheo. iskop., 2006. god.; sjeverno unutarnje grabište, sonda/blok: S.VII, S.J.008.

Tip: Istočni, austrougarski. Neobjavljeno.

21. Lula, dimenzije: U. P. T. $=0,9 \mathrm{~cm}$, (N. S.) V. $=1,7 \mathrm{~cm}$

Zbirka i inventarni broj: Z. gr. arheo., GMV-88719

Nalazište: Vž., Preradovićeva 14, M. Korunek, zaštit. arheo. iskop., 2007. god., sonda/blok: S. I, S.J. 1, sloj: recentni nasip.

Tip: Istočni, austrougarski. Neobjavljeno.

22. Lula, dimenzije: U. P. T. $=1,1$, (N. S.) V. $=2,2 \mathrm{~cm}$

Zbirka i inventarni broj: Z. gr. arheo., GMV- 53241

Nalazište: Vž. Stari grad, M. Šimek, arheo. iskop., 2006. god.; sjeverno unutarnje grabište, sonda/blok: S.VII, S.J.013.

Tip: Istočni, austrougarski. Neobjavljeno.

23. Lula, dimenzije: P. P. D. $=1,8 \mathrm{~cm}$, U. P. T. $=1,4 \mathrm{~cm}$, D. S. Č $=0,3 \mathrm{~cm}$, (N. S.) V. $=3 \mathrm{~cm}$ Zbirka i inventarni broj: Z. gr. arheo., GMV-53242

Nalazište: Vž. Stari grad, M. Šimek, arheo. iskop., 2006. god.; sjeverno unutarnje grabište, sonda/blok: S.VII, S.J.008.

Tip: Istočni, austrougarski. Neobjavljeno.

24. Lula, dimenzije: U. P. T. $=1,2 \mathrm{~cm}$, (N. S.) V. $=2,4 \mathrm{~cm}$

Zbirka i inventarni broj: Z. gr. arheo., GMV-53144 
Nalazište: Vž. Stari grad, M. Šimek, arheo. iskop., 2006. god.; sjeverno grabište, sonda/blok: S.VIIA, dubina: $130 \mathrm{~cm}$, S.J.017.

Tip: Istočni, austrougarski, Podrečany. Neobjavljeno.

25. Lula, dimenzije: P. P. D. $=1,9 \mathrm{~cm}$, U. P. T. $=1,2 \mathrm{~cm}$, D. S. Č. $=0,4 \mathrm{~cm}$, (N. S.) V. $=3,5 \mathrm{~cm}$ Zbirka i inventarni broj: Z. gr. arheo., GMV AO-6594.

Nalazište: Crkva Sv. Florijana. M. Šimek, zaštit. arheo. iskop., 2001. god., ${ }^{70}$ iskop II - uz sjevernu fasadu crkve, sloj šute ispod humusa.

Tip: Istočni, austrougarski, kavanski, Beč-Meidling. Objavljeno. ${ }^{71}$

26. Lula, dimenzije: P. P. D. $=1,8 \mathrm{~cm}$, U. P. T. $=1,2 \mathrm{~cm}$, D. S. Č. $=0,3 \mathrm{~cm},($ N. S.) V. $=3 \mathrm{~cm}$. Zbirka i inventarni broj: Z. gr. arheo., GMV-53238.

Nalazište: Vž. Stari grad, M. Šimek, arheo. iskop., 2006. god., sjeverno unutarnje grabište, sonda/blok: S.VIIA, dubina: $30 \mathrm{~cm}$, N-profil.

Tip: Istočni, austrougarski, kavanski, Köln. Objavljeno. ${ }^{72}$

27. Lula, dimenzije: P. P. D. $=1,8 \mathrm{~cm}$, U. P. T. $=1,4 \mathrm{~cm}$, D. S. Č. $=0,3 \mathrm{~cm}$, (N. S.) V. $=5 \mathrm{~cm}$ Zbirka i inventarni broj: Z. gr. arheo., GMV-88727.

Nalazište: Vž., Vodnikova ul., M. Jurišić, zaštit. arheo. iskop., 2007. god.; sonda/ blok: S.II, S.J. 016. Tip: Istočni, austrougarski, kavanski, Kolin. Neobjavljeno.

28. Lula, dimenzije: P. P. D. $=1,8 \mathrm{~cm}$, U. P. T. $=1 \mathrm{~cm}$, D. S. Č. $=0,3 \mathrm{~cm}$, (N. S.) V. $=5,3 \mathrm{~cm}$ Zbirka i inventarni broj: Z. gr. arheo., GMV-88726.

Nalazište: Vž., Vodnikova ul., M. Jurišić, zaštit. arheo. iskop., 2007. god.; sonda/ blok: S.II, S.J. 016. Tip: Istočni, austrougarski, kavanski, Kolin. Neobjavljeno.

29. Lula, dimenzije: P. P. D. $=1,7 \mathrm{~cm}$, U. P. T. $=1 \mathrm{~cm}$, D. S. Č $=0,3 \mathrm{~cm}$, (N. S.) V. $=5,7 \mathrm{~cm}$ Zbirka i inventarni broj: Z. gr. arheo., GMV-88725.

Nalazište: Vž., Vodnikova ul., M. Jurišić, zaštit. arheo. iskop., 2007. god.; sonda/ blok: S.II. S.J. 016 Tip: Istočni, austrougarski, kavanski, Kolin. Neobjavljeno.

30. Lula, dimenzije: P. P. D. $=1,6 \mathrm{~cm}$, U. P. T. $=1,4 \mathrm{~cm}$, D. S. Č. $=0,3 \mathrm{~cm}$, (N. S.) V. $=3,9 \mathrm{~cm}$ Zbirka i inventarni broj: Z. gr. arheo., GMV- 88728.

Nalazište: Vž., Vodnikova ul., M. Jurišić, zaštit. arheo. iskop., 2007. god., sonda/ blok: S.II, S.J. 016. Tip: Istočni, austrougarski, kavanski, Kolin. Neobjavljeno.

70 Zaštitno iskopavanje prilikom sanacije temelja i poda crkve od djelovanja površinske i podzemne vode. Dokumnetacija o ovim istraživanjima se nalazi u arhivi Ao GMV-a.

71 Marina ŠIMEK, Ispod varaždinskih pločnika, Izložbeni salon kuće Padovec TZ Grada Varaždina, katalog izložbe GMV-a, Varaždin, 2002.

72 S. TEŽAK, M. KLEMM, M. ŠIMEK, n. dj., 42, kat. 68. 
Jere Drpić: Glinene lule iz fundusa Arheološkog odjela Gradskog muzeja Varaždin

Radovi Zavoda za znanstveni rad HAZU Varaždin; br. 29, 2018., str. 9-41

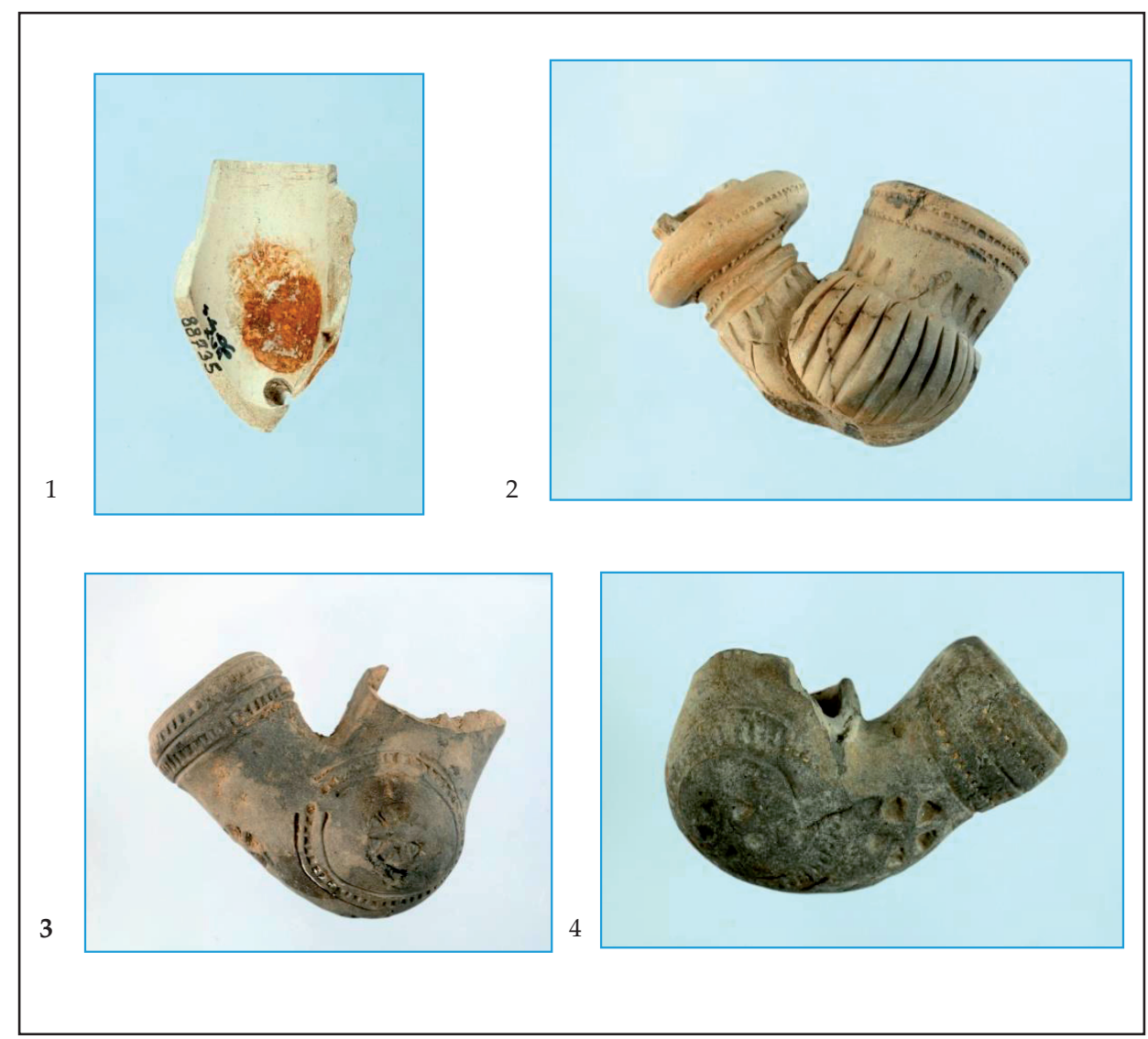

T. I kat. 1-4 (foto: A. Švoger) 


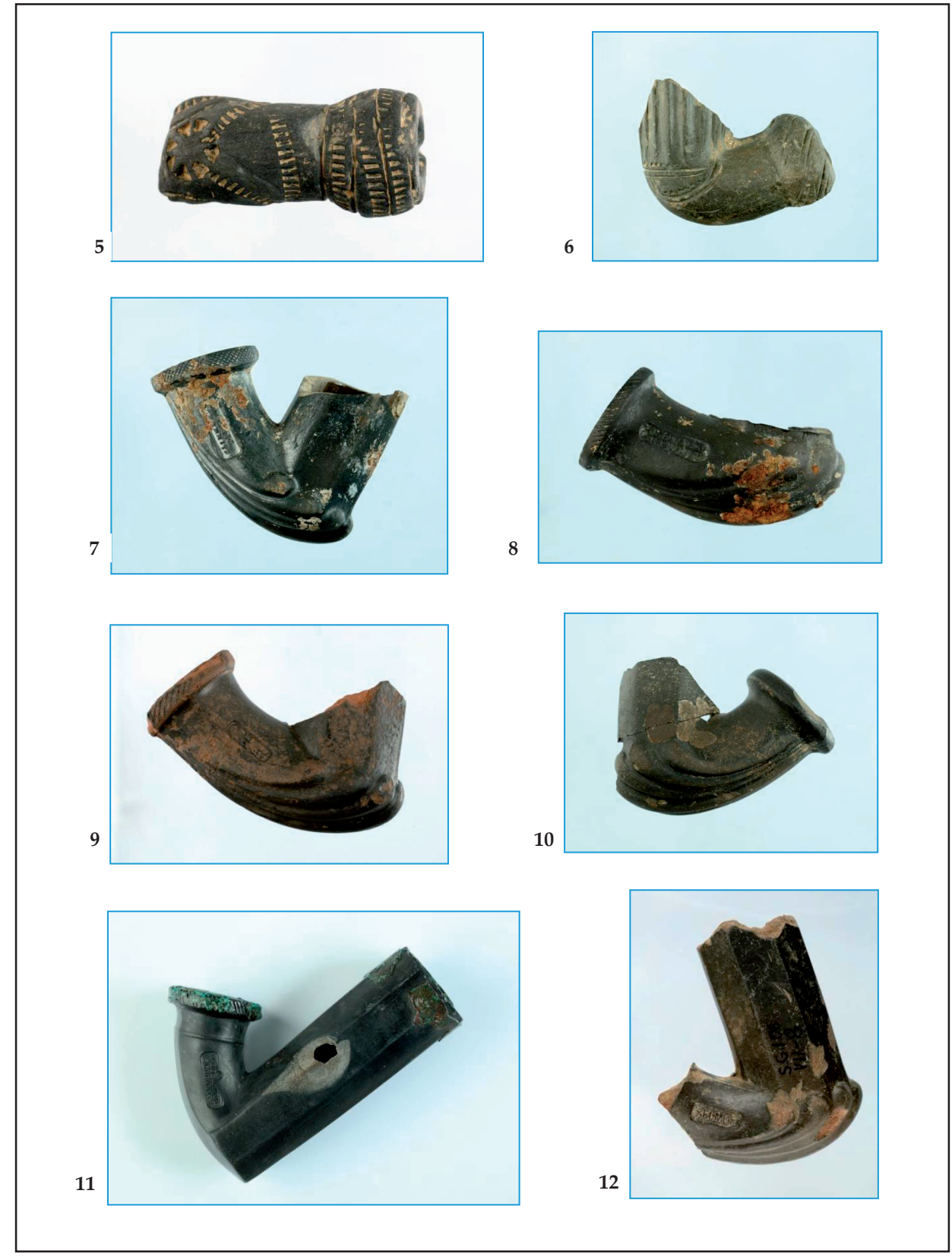

T. II kat. 5-12 (foto: A. Švoger) 


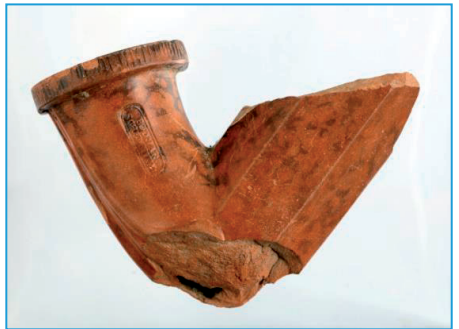

14

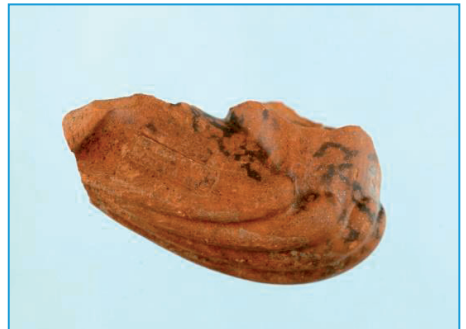

15

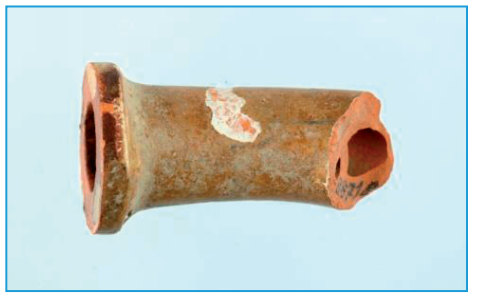

16
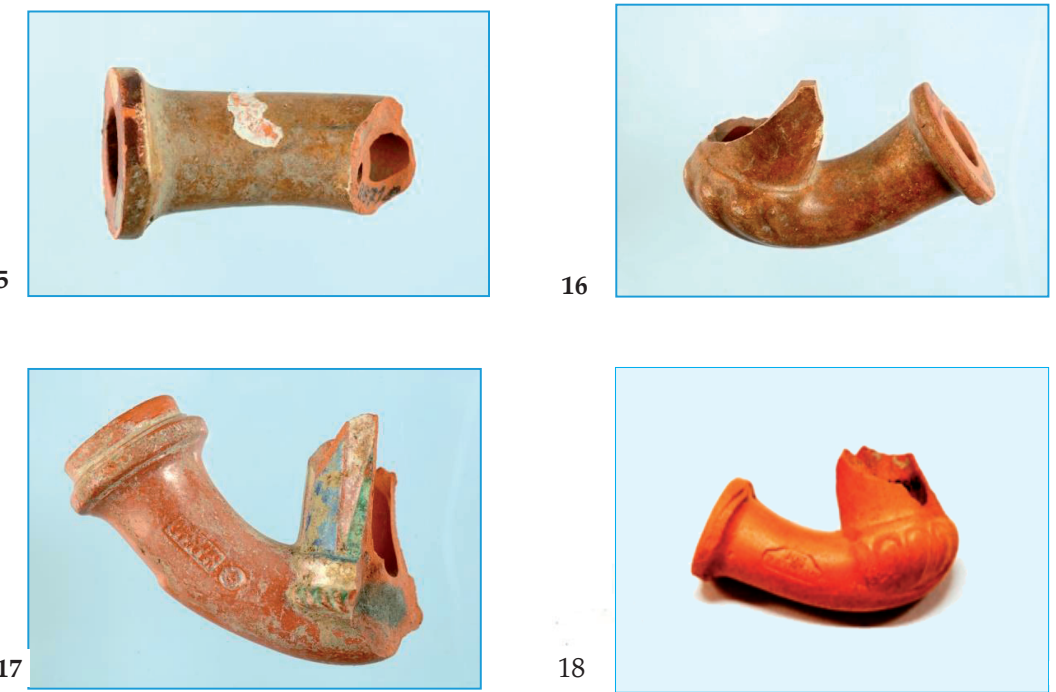

18
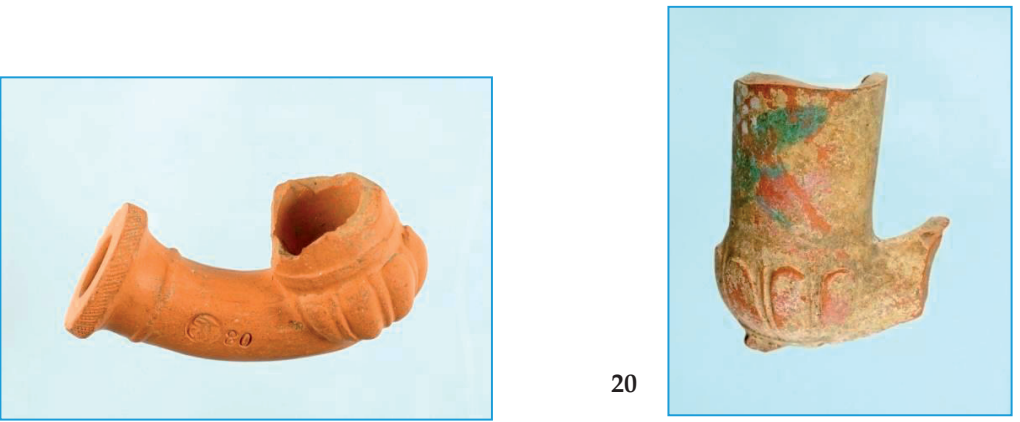

T. III kat. 13-20 (foto: A. Švoger) 


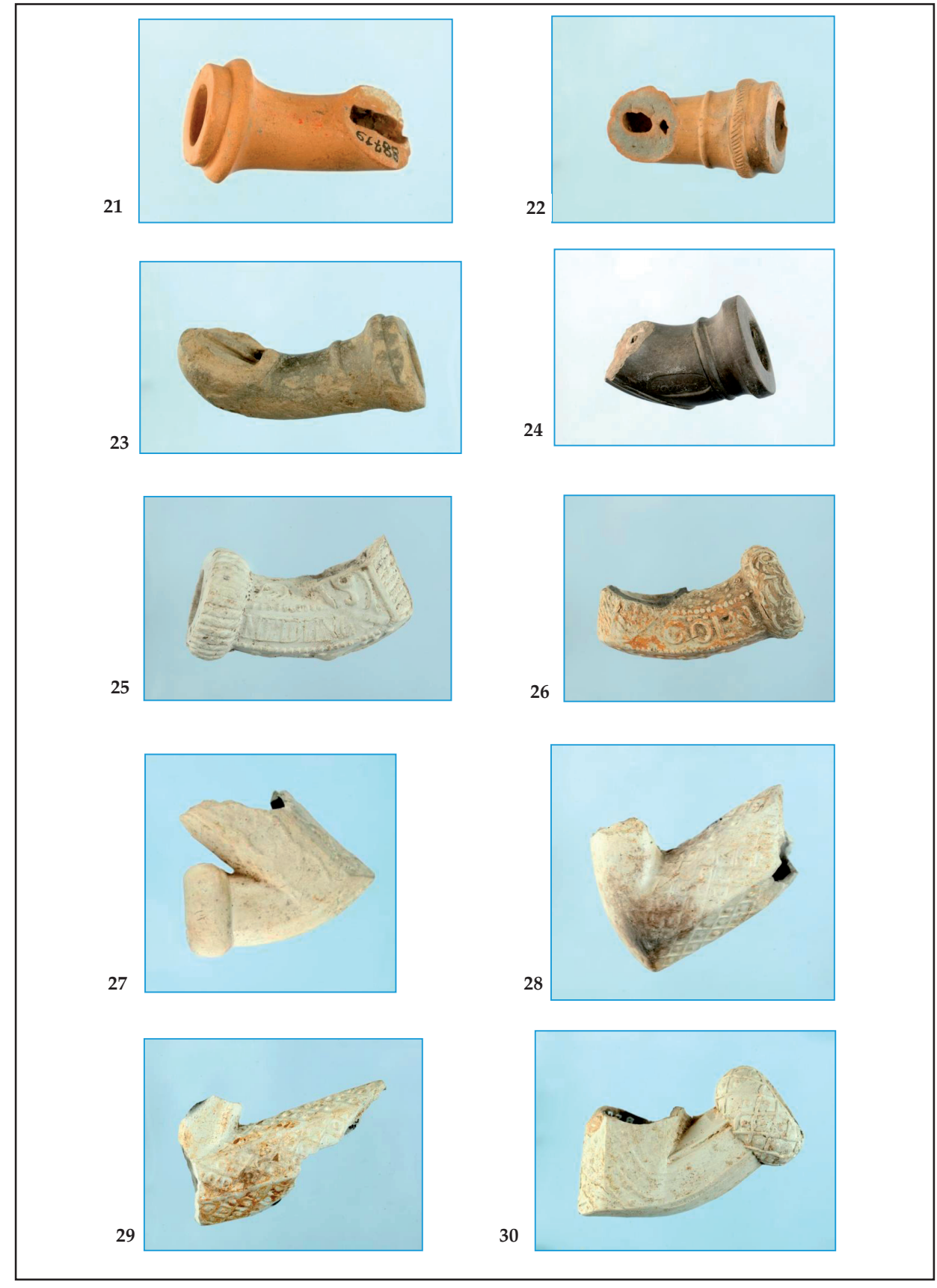

T. IV kat. 21-30 (foto: A. Švoger) 


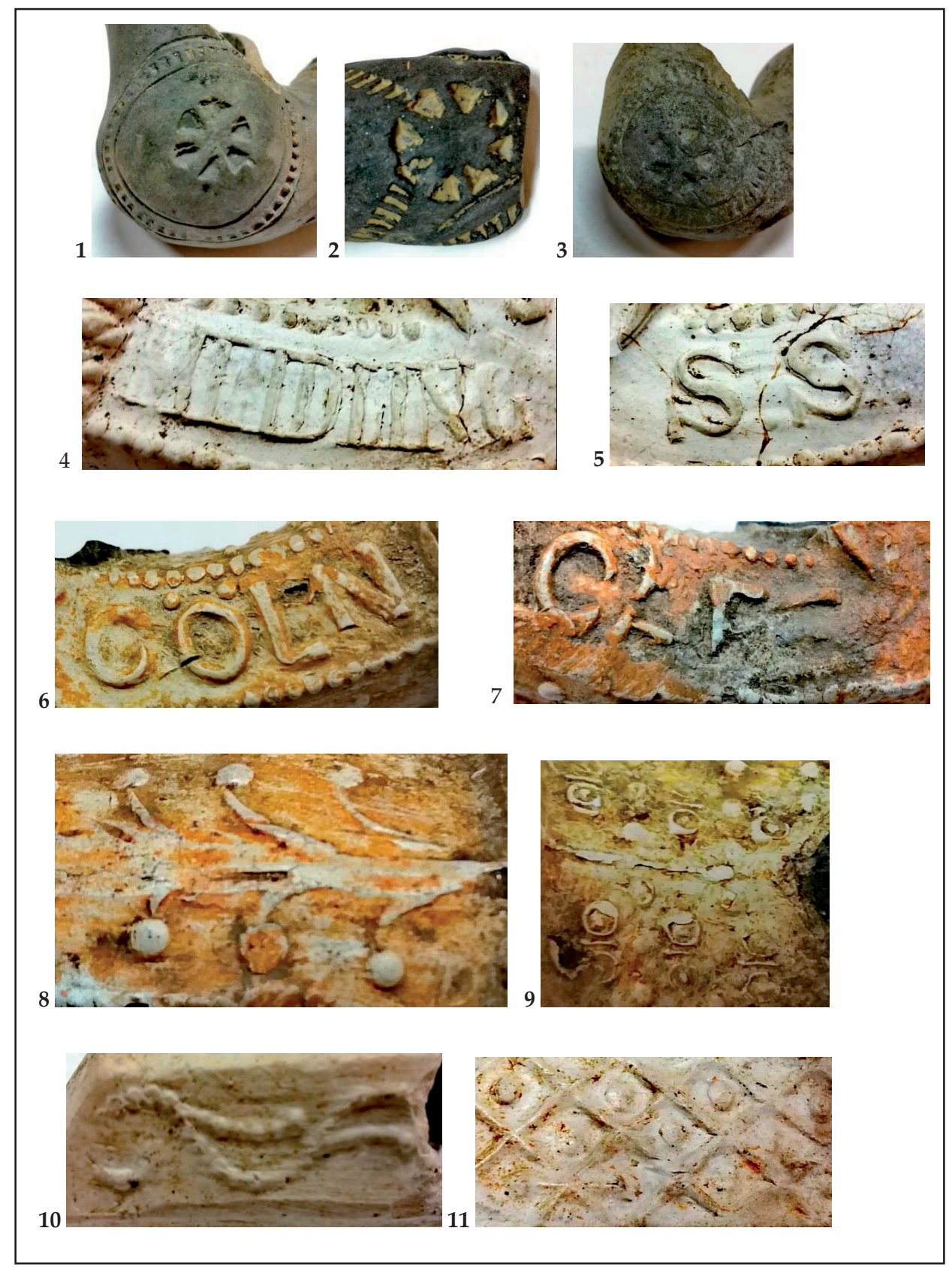

T. V 1-11, Ukrasi i pečati (foto: J. Drpić). 


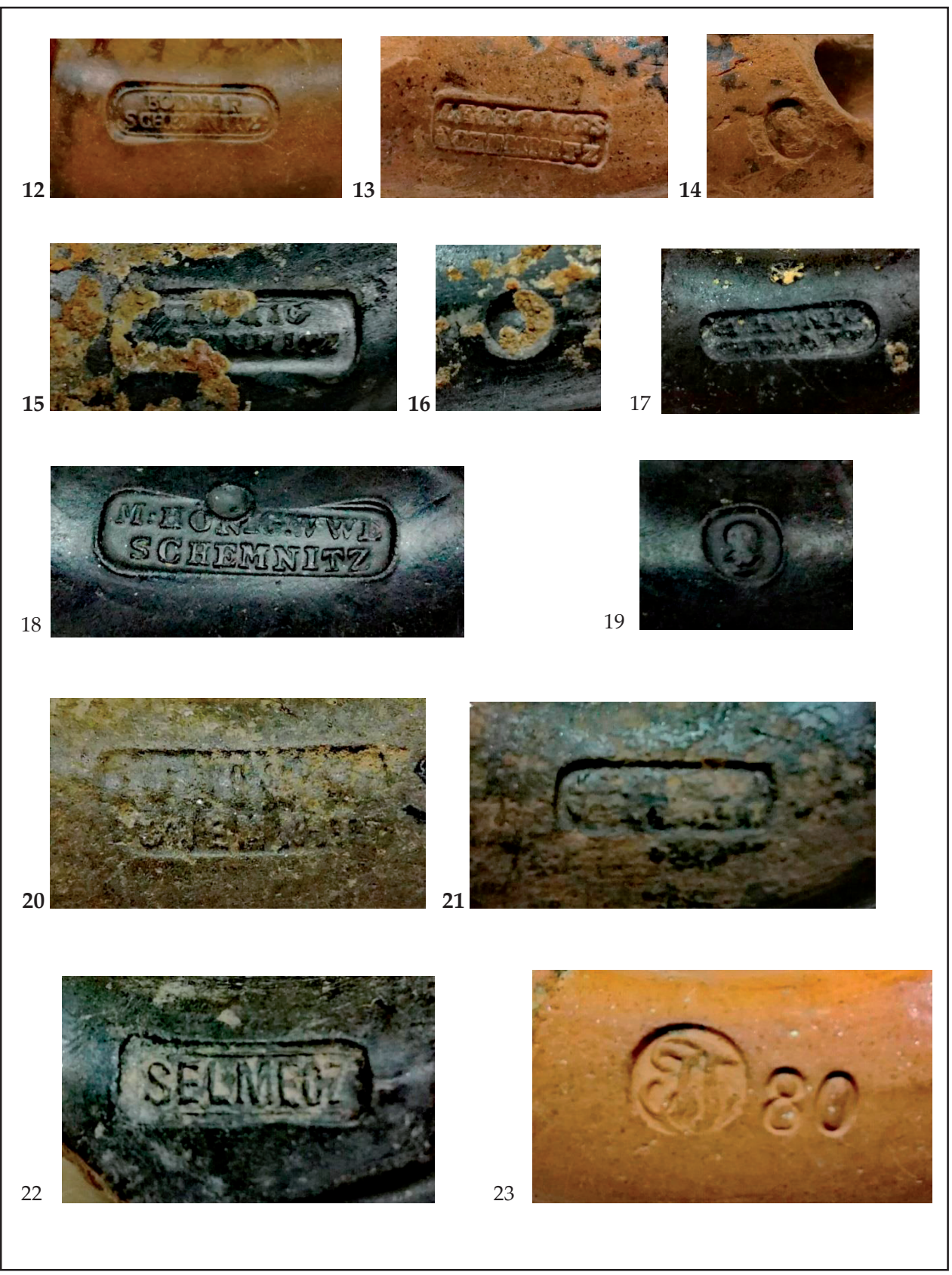

T. VI 12-23, Ukrasi i pečati (foto: J. Drpić). 
Jere Drpić: Glinene lule iz fundusa Arheološkog odjela Gradskog muzeja Varaždin

Radovi Zavoda za znanstveni rad HAZU Varaždin; br. 29, 2018., str. 9-41

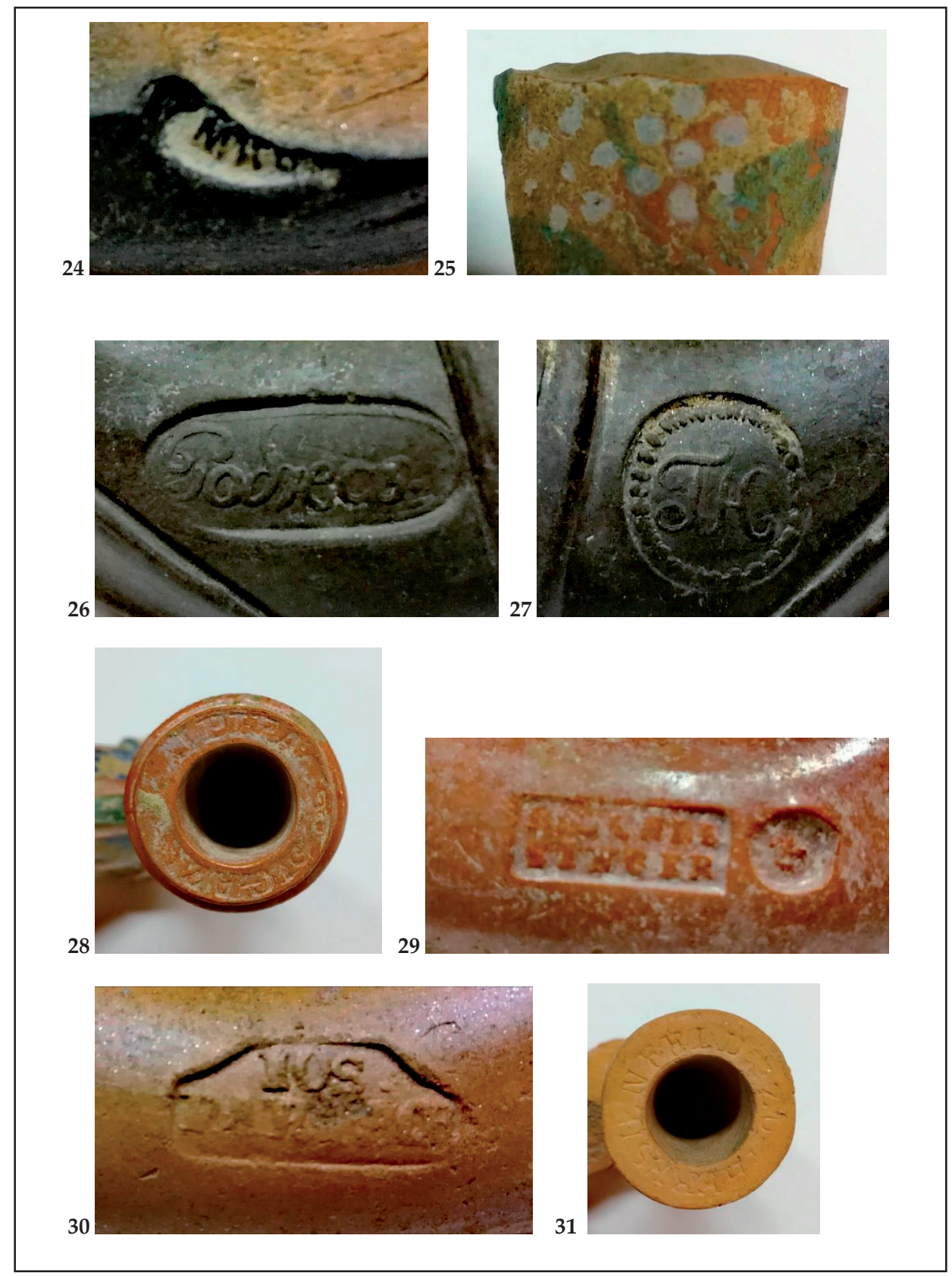

T. VII 24-31, Ukrasi i pečati (foto: J. Drpić). 
Jere Drpić: Glinene lule iz fundusa Arheološkog odjela Gradskog muzeja Varaždin

Radovi Zavoda za znanstveni rad HAZU Varaždin; br. 29, 2018., str. 9-41

\section{LITERATURA}

1. Luka BEKIĆ, Uvod u problematiku glinenih lula na području Hrvatske, Vjesnik Arheološkog muzeja u Zagrebu 3.s., XXXII-XXXII, 1999/2000., 249-279.

2. Luka BEKIĆ, Glinene lule s utvrde Čanjevo, Utvrda Čanjevo. Istraživanja 20032007. Visoko: Hrvatski restauratorski zavod; Općina Visoko, 2008, , str. 191195.

3. Luka BEKIĆ, A Brief Introduction to Clay Pipe Finds in Croatia With Special Attention to Local Pipes Found at Fort Canjevo in The Kalnik Hills, Journal of the Académie Internationale de la Pipe, Vol. 3., 2010, 1-7.

4. Luka BEKIĆ, Novovjekovne lule i boce iz podmorja Istre / Post medieval Pipes and Bottles from the Istrian Seabed, Istra u novom vijeku / Istria in the modern period, Monografije i katalozi Arheološkog muzeja Istre u Puli 30, Pula, 2017, 217-298.

5. Luka BEKIĆ, Duhanske lule iz nekadašnje vojarne sv. Nikola u Zadru, Sveti Nikola u Zadru, Arheološko iskopavanje u samostanskom sklopu sv. Nikola u Zadru, 2014.-2016, Zadar, 2017, 137-149.

6. Juraj BELAJ, Ivanec kroz slojeve prošlosti; deset godina arheoloških istraživanja u Ivancu, Ivanec, 2008.

7. Mario BIELICH, Marian ČURNY, Pipe finds from Nitra and Nitra pipe production, Studies in Post-medieval Archaeology 3., Prague, 2009, 337-362.

8. Zdenko BRUSIĆ, Dio tereta s lađe iz 17. stoljeća potonule kod otoka Bisaga u Kornatskom arhipelagu Prilozi povijesti umjetnosti u Dalmaciji 26/1986/87, $473-490$.

9. Lioyd EDWARDS, The Archaeology of the Clay Tobacco Pipe, XI. Seventeenth and Eighteenth Century Tyneside Tobacco Pipe Makers and Tobacconists, BAR, British series 192, 1988, 8-13.

10. Blaženka FIRST, Mateja KOS, Darija MAVRIČ, Tomaž NEBERGOJ, Nika VERŠNIK, Matija ŽARGI, 2009., Modern period, The Ljubljanica - a river and its past, Ljubljana, 2009, 374-464.

11. Divna GAČIĆ, The pipes from Museum Collections of Serbia, Novi Sad, Muzej grada Novog Sada, 2011.

12. Iain GATELY, Tobacco: A Cultural History of how an Exotic Plant Seduced Civilization, London: Grove Press, 2001.

13. Karla GUSAR, Arheološki nalazi keramičkih lula za duhan iz zbirke Narodnog muzeja u Zadru. U: Prilozi instituta za arheologiju Zagreb 25, 2008, 35-154.

14. Miroslav HARMAN, Jozef ŠTEFFEK, Fajka velebená, fajka zatracovaná, Tlmače, 2008.

15. Rudolf HORVAT, Povijest grada Varaždina. Varaždin: Hrvatska akademija znanosti i umjetnosti - Zavod za znanstveni rad, Varaždin, 1993. 
16. Mira ILJANIĆ, Varaždin u 16. st., Radovi Zavoda za znanstveni rad Jugoslavenske akademije znanosti i umjetnosti, 2, Varaždin, 1988., 447-457.

17. Aleksandar JAŠAREVIĆ, Keramičke lule za duvan iz arheološke zbirke Muzeja u Doboju, Radovi, knjiga 5, Sarajevo, 2018., 213-236.

18. Ralf KLUTTIG-ALTMANN, Mehr als blauer Duns - Tönerne Tabakspfeifen aus Laipziger Stadtkerngraburgen, Archaologie aktuell 6, Fraistaat Sachsen, 1998/99, 146-153.

19. Gyöngyi KOVACS, Cseréppipák a 17-18. századból', Budapest Régiségei 38, 121-131, 2004.

20. Gyöngyi KOVACS, Rozsas MARTON, KORA ÚJKORI CSERÉPPIPÁK A DRÁVA VIDÉKÉRŐL, Egység, regionalitás, kereskedelem, Archaeologiai Értesítő 139, Budapest, 2014., 239-259.

21. Ivy LENTIĆ-KUGLI, 1975., Prilog istraživanju varaždinskih svratišta, gostiona i kavana u 18. st. i prvoj polovini 19. st. U: Godišnjak Gradskog muzeja Varaždin 5, str. 53-65.

22. Curt MARONDE, Rund um Tabak. Frankfurt am Main, Robugen GmbH, 1976.

23. Walter MORGENROTH, Das Geheimnis Der Echten Schemnitzer Tabakspfeifen, KnasterKOPF 14, Höhr-Grenzhausen 2001., 53-59.

24. Branka MILOŠEVIĆ, Nikolina TOPIĆ, Keramičke lule s lokaliteta Kula Gornji ugao u Dubrovniku., Starohrvatska prosvjeta III. serija - svezak 38, $2011 .$, 297-328.

25. Branka MILOŠEVIĆ, Nikolina TOPIĆ, Nalazi keramičkih lula s lokaliteta Sv. Marija od Kaštela i Posat od Ploča u Dubrovniku, Starohrvatska prosvjeta III. serija - svezak 39/2012., 257-271.

26. Vladimir MITAŠ, Zuzana POLAKOVA, Keramické fajky z archeologických nálezísk Gemera-Malohontu a Novohradu, Zbornik Gemersko-malohontskeho muzea v Rimavskej Sobote, ročnik 11, 2015., 56-78.

27. Zoltan NAGY,Transdanubian Pipe Manufacturers Associated with Selmecbánya, The History of the Hungarian Pipemaker's Craft: Hungarian History through the Pipemaker's Art, Budapest: Hungarian National Museum, 2000., $45-54$.

28. Hrvoje PETRIĆ, O požarima i urbanom okolišu slobodnih kraljevskih gradova Hrvatsko-Slavonskog kraljevstva u ranom novom vijeku (Varaždin, Križevci, Koprivnica, Zagreb), Ekonomska i ekohistorija: Časopis za gospodarsku povijest i povijest okoliša 5, 2009., 158-191.

29. Michal PREUSZ, Novověké dýmky v jižních Čechách : Nálezy ze sbírky Jihočeského muzea v Českých Budějovicích, Archeologické výzkumy v jižních Čechách 29, 2016., 99-408. 
30. Mladen RADIĆ, Zvonko BOJČIĆ., Srednjovjekovni grad Ružica. Katalog izložbe, Osijek: Muzej Salvonije, 2004.

31. Rebecca C. W. ROBINSON, Tobacco pipes of Corinth and of Athenian Agora, Hesperia 54-2/1985., 1985., 149-153.

32. Amoret SCOTT, Christopher SCOTT, Discovering smoking antiques, Tring: Shire, 1970.

33. Magdalina STANČEVA, O proizvodnji keramičkih lula u Bugarskoj, Zbornik Muzeja primenjene umetnosti 19-20, Beograd, 1976., 129-138.

34. Marina ŠIMEK, Ispod varaždinskih pločnika, Izložbeni salon kuće Padovec TZ Grada Varaždina, katalog izložbe GMV-a, Varaždin, 2002.

35. Marija ŠIŠA-VIVEK, Krešimir FILIPEC, Keremičke lule s lokaliteta Zoljani Čemešac I, Opuscula archaeologica 37/38, 2013/2014., 301-333.

36. Spomenka TEŽAK, Miroslav KLEMM, Marina ŠIMEK, Iz srednjega u novi vijek: Varaždinski Stari grad i project Bastion, Katalog izložbe, Gradski muzej Varaždin, Varaždin, 2008.

37. Martin VYŠOHLID, Clay Tobacco Pipes in Bohemia, Journal of the Académie Internationale de la Pipe, Vol. 2, 2009., 17-25.

38. Martin VYŠOHLID, Keramické dýmky v archeologických nálezech a jejich vypovídací možnosti : Clay tobacco pipes in the archaeological finds and their ability to testify, Archeologie ve Strednich Čechach 13, 2009., 965-1000.

39. Martin VYŠOHLID, Dymky z Archeologickeho vyzkumu v Dolnorakovskem meste Hainburg an der Donau, Historia vyroby fajok a archeologicke nalezy fajok na Slovensku II, Tekovske Muzeum v Leviciach, 2016., 4-10.

40. Elvin ZEJNILHODŽIĆ, Lule iz Novovjekovne zbirke arheološkog muzeja Istre, Histria archaeologica, 43, 2012., 163-191.

41. Izvori sa interneta: www.udaljenosti.com (7. 9. 2018.); www.podrecany.sk (25. 8. 2018.)

42. Ostala korištena dokumentacija: Arhiva dokumentacije Arheološkog odjela Gradskog muzeja Varaždin. 


\section{SAŽETAK \\ GLINENE LULE IZ FUNDUSA ARHEOLOŠKOG ODJELA GRADSKOG MUZEJA VARAŽDIN}

Glinene lule iz zbirki Arheološkog odjela Gradskog muzeja Varaždin nađene su u arheološkim istraživanjima, uz jedan izuzetak, na širem prostoru Varaždinske županije. Tako imamo lulu iz Lepoglave te dvije iz špilje Vindija. Ipak najveći broj njih nađen je na prostoru stare gradske jezgre Varaždina (27) tj. u mokrom jarku utvrde Stari grad. Također više njih potječe iz arheoloških nadzora u samom gradu; Vodnikovoj i Preradovićevoj ulici, te iz okolice crkve sv. Florijana. Sve ove lule pripadaju istočnoj ili mediteranskoj skupini, uz jedan izuzetak koji pripisujemo zapadnoj, a nađena u jarku Starog grada, (kat. 1). Istočna je zastupljena sa dva glavna tipa; austrougarskim i turskim. Austrougarskom tipu pripada većina nalaza (kat. 7-30), a unutar njega se javlja i veća grupa Schemnitza lula iz Banske Štiavnice ili njihove imitacije (kat. 7-16), sa pečatima radionica M. Hönig Schemnitz, Bodnar Schemnitz, Leop. Gross Schemnitz, Selmecz. Datiraju se u 19. st. Grupu lula (kat. 18-23) možemo pripisati austrijskim radionicama, a radionici Josepha Partscha u Theresienfeldu se pripisuje prema pečatu lula (kat. 18). Primjerak, (kat. 17) sa pečatom LSLESINGER pripisujemo mađarskoj radionici u gradu Papa, dok lulu (kat. 24) sa pečatom PODRECS, proizvodnji u slovačkoj radionicu u Podrečanyu. Javlja se i grupa tzv. kavanskih lula (kat. 25-30), koje pripisujemo poizvodnji u Meidlingu, Beč (kat. 25), zatim u njemačkom gradu Kölnu (kat. 26) i slovačkom Kolinu (kat. 27-30). Ovu proizvodnju u Kolinu prepoznajemo prema tipičnim mrežastim ukrasima, a sve se datiraju u drugu pol. 19. st. Turski tip je zastupljen sa 5 primjeraka (kat. 2-6). Radi se o grupi lula koje možemo pripisati tzv. krajiškom podtipu. Spadaju u grupu najstarijih zasada pronađenih lula u Hrvatskoj iz druge pol. 17. st. Kronološki ova grupa lula iz GMV-a sa trideset primjeraka obuhvaća period od samih početaka pušenja u 17. st., pa sve do kraja masovne upotrebe i proizvodnje krajem 19. st.

Ključne riječi: duhan; glinene lule; Varaždin; Varaždinska županija. 


\section{SUMMARY}

\section{CLAY TOBACCO PIPES FROM THE ARCHAEOLOGICAL DEPARTMENT COLLECTION OF THE VARAŽDIN CITY MUSEUM}

Clay tobacco pipes from the collection of the Archaeological Department of the Varaždin City Museum were found during archaeological research, with one exception, in the wider area of Varaždin County. So, there is a pipe from the city of Lepoglava and two from the cave Vindija. Nevertheless, most of them were found in the area of the historic nucleus of the city Varaždin (27), in the wet ditch of the varaždin fortress colled Stari grad. Also, more of them are a result of the archaeological surveillance in the city itself; In the streets of Branko Vodnik and Petar Preradović, and from the surroundings of the church of St. Florian. All of these pipes belong to the eastern or Mediterranean group, with one exception that we attribute to the west, that is found in the ditch of the Old Town (cat. 1). The east is represented by two main types; Austro-Hungarian and Turkish. Most of the findings belong to the Austro-Hungarian type (cat. 7-30), and within them there is a larger group of Schemnitza pipe from Ban Štiavnica or their imitations (Grades 7-16), with the stamps of the workshops M. Hönig Schemnitz, Bodnar Schemnitz, Leop. Gross Schemnitz, Selmecz. They are to be traced to the 19th century of the pipe group (cat. 18-23) and can be attributed to Austrian workshops, and to the workshop of Josepha Partscha in Theresienfeld due to the stamp of the pipe (cat. 18). The examples (cat. 17) with the stamp LSLESINGER are attributed to the Hungarian workshop in the town of Papa, and the postal code PODRECS (cat. 24) are attributed to the production at the slovak workshop in Podrečany. There is also a group of so called café tobacco pipe (cat. 25-30), which we attribute to the production in Meidling, Vienna (cat. 25), then in the german city Cologne (cat. 26) and slovak Kolin (cat. 27-30). This production in Kolin can be recognized by the typical net decorations, which all date to the half of the $19^{\text {th }}$ century. Turkish type is represented by 5 samples (cat. 2-6). It is a group of pipes that can be attributed to the so-called Borderland-type pipes. They belong to the group of the oldest found pipes of Croatia in the second half of the 17th century, and were used in borderland areas colled Vojna krajina or Militärgrenze, the area under militar rule of Habsburg monarchy, bordering the Ottoman Empire. Chronologically, this whole group of pipes from the Varaždin City Museum with 30 samples covers the period from the very beginnings of smoking in the 17th century, until the end of mass production and production at the end of the 19th century.

Key Words: tobacco; clay pipes; Varaždin; Varaždin county. 